\title{
Amending subsoil with composted poultry litter: Effects on soil physical and chemical properties, turfgrass establishment and weed pressure
}

Mili Mandal

West Virginia University

Follow this and additional works at: https://researchrepository.wvu.edu/etd

\section{Recommended Citation}

Mandal, Mili, "Amending subsoil with composted poultry litter: Effects on soil physical and chemical properties, turfgrass establishment and weed pressure" (2005). Graduate Theses, Dissertations, and Problem Reports. 4172.

https://researchrepository.wvu.edu/etd/4172

This Thesis is protected by copyright and/or related rights. It has been brought to you by the The Research Repository @ WVU with permission from the rights-holder(s). You are free to use this Thesis in any way that is permitted by the copyright and related rights legislation that applies to your use. For other uses you must obtain permission from the rights-holder(s) directly, unless additional rights are indicated by a Creative Commons license in the record and/ or on the work itself. This Thesis has been accepted for inclusion in WVU Graduate Theses, Dissertations, and Problem Reports collection by an authorized administrator of The Research Repository @ WVU. For more information, please contact researchrepository@mail.wvu.edu. 


\title{
Amending Subsoil with Composted Poultry Litter: Effects on Soil Physical and Chemical Properties, Turfgrass Establishment and Weed Pressure
}

\author{
Mili Mandal \\ Thesis submitted to the \\ Davis College of Agriculture, Forestry and Consumer Sciences \\ at West Virginia University \\ in partial fulfillment of the requirements \\ for the degree of \\ Master of Science \\ in \\ Plant and Soil Sciences
}

\author{
Rakesh S. Chandran, Ph.D., Chair \\ John A. Balasko, Ph.D. \\ John C. Sencindiver, Ph.D.
}

Division of Plant and Soil Sciences
Morgantown, West Virginia
2005

Keywords: Composted poultry litter, cation exchange capacity, organic matter, subsoil, turfgrass, weeds 


\title{
Abstract \\ Amending Subsoil with Composted Poultry Litter: Effects on Soil Physical and \\ Chemical Properties, Turfgrass Establishment, and Weed Pressure
}

\begin{abstract}
Mili Mandal
Experiments were established in fall 2003 at West Virginia University to evaluate the effects of incorporation of composted poultry litter (CPL) on subsoil physical and chemical properties, Kentucky bluegrass (Poa Pratensis L.) establishment, root depth, and weed pressure. Twenty $\mathrm{cm}$ of topsoil was removed and CPL was incorporated to a depth of $12.7 \mathrm{~cm}$ at $10 \%, 20 \%$, and $40 \% \mathrm{v} / \mathrm{v}$ prior to seeding or sodding. Composted plots were compared to $\mathrm{N}$-fertilized $\left(454 \mathrm{Kg} \mathrm{ha}^{-1}\right)$ and control plots. Positive linear increases in total water content $\left(\theta_{T}\right)$, organic matter, $\mathrm{pH}$, and CEC were observed following compost incorporation with a decrease in available water $\left(A_{v}\right)$ and soil bulk density. Kentucky bluegrass yields and root depth increased linearly with compost rates. One year after seeding, all compost-treated plots exhibited 100\% turf cover. Fertilized plots showed 20\% less turfgrass growth than control plots and exhibited weed pressure similar to the control. Overall, compost treatments were able to maintain superior turf cover and quality with lower weed populations compared to fertilized and control plots by improving soil physical and chemical properties.
\end{abstract}


To my husband, Preetanshu, for love and guidance, and my parents for their unprecedented support.... 


\section{Acknowledgements}

I want to acknowledge and express my sincere thanks to Dr. Rafif Srour, for her untiring support, advice, and encouragement as a scientist. She has been a wonderful friend, a mentor, and a confidant to me during my stay at WVU. When things were darkest, Dr. Srour was there to cheer me and motivate me to finish. I'd like to thank my advisor Dr. Rakesh Chandran for giving me an opportunity to enhance my knowledge. Many thanks to Dr. Barton Baker for his time, generous advice, and support. $\mathrm{He}$ encouraged me to have faith in myself and finish this program successfully. I'd like to acknowledge Dr. Louis McDonald, who has been generous in sharing his time, expertise, and equipments. His example helped me to continue develop interest in science and outreach. I also want to thank my committee members, Dr. John A. Balasko and Dr. John C. Sencindiver for their valuable suggestions.

Thanks to all my friends at WVU especially, Christina, Evans, Marcela, and Wendy with whom it has been my genuine pleasure to work. I'd also like to thank everyone at greenhouse, especially Gale, Carole, and Sue for their loving support, appreciation, and sympathetic ear. They helped me to remember that it is possible to do science and enjoy life: thanks for all the flowers, plants, and delicious cookies they provided me.

Finally, I want to acknowledge my family who mean the world to me. My father, Capt. Alok Mandal for his enthusiastic drive, my mother, Mrs. Indira Mandal for her unparalled faith in me, and my sister, Nidhi, for her special love and sense of humor which enables me to become a better person each day, and also, my in laws, Dr. \& Mrs. O.P. Pandey and my sister-in-law, Dr. Pragya Pandey, for their exceptional love and care and for always making me feel special. Most of all, I want to acknowledge my husband, Preetanshu, who has been a boyfriend, husband, field assistant, editor, and counselor. I couldn't have done it without his help and patience. Thanks for always being there for me. I love you! 


\section{Table of Contents}

Abstract
Acknowledgements
Table of Contents

3. Amending Subsoil with Composted Poultry Litter- I: Effects on Soil Physical

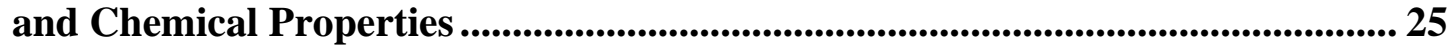

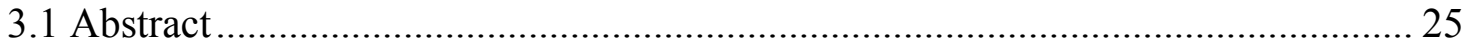



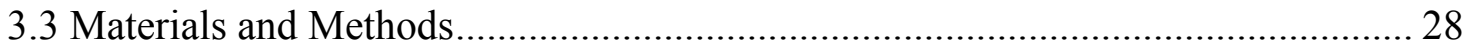

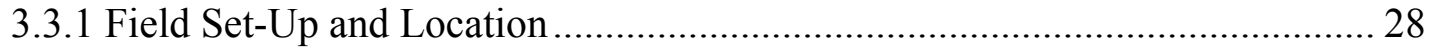

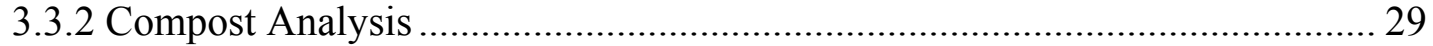

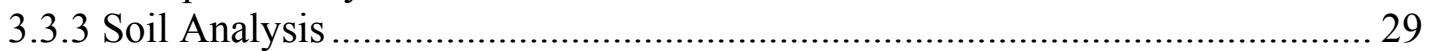

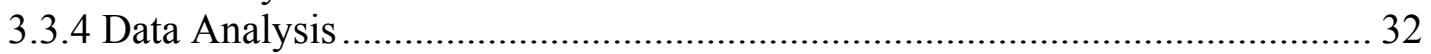

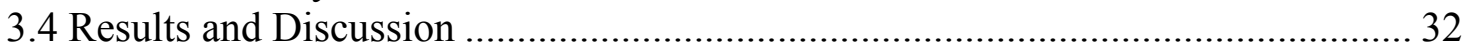

3.4.1 Total Water Content and Soil Organic Matter ............................................. 34

3.4.2 Available Water Capacity and Soil Bulk Density $\quad$................................... 37



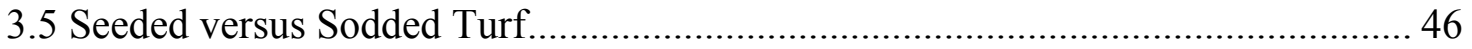

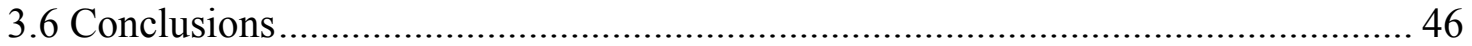

4. Amending Subsoil with Composted Poultry Litter-II: Effects on Turfgrass Establishment, Root Growth and Weed Pressure ............................................... 48

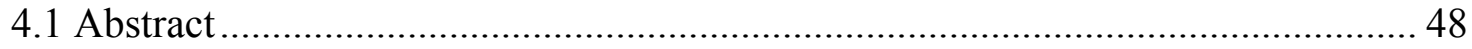

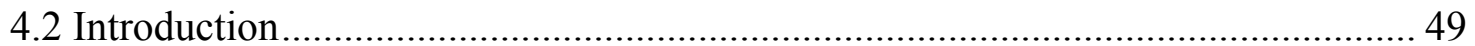

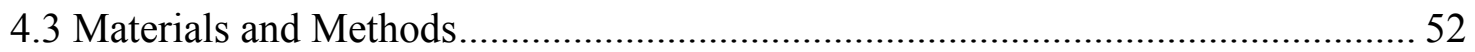

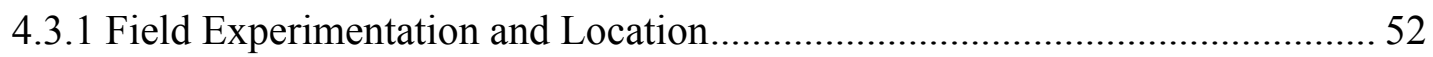

4.3.2 Evaluation of Turfgrass Establishment and Growth ................................... 53 


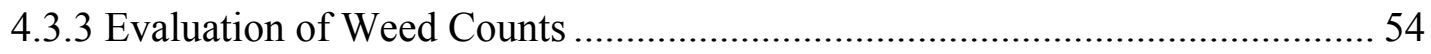

4.3.4 Greenhouse Study and Evaluation of Turfgrass Root Depth........................ 55

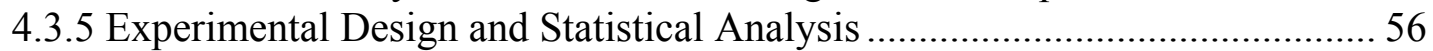

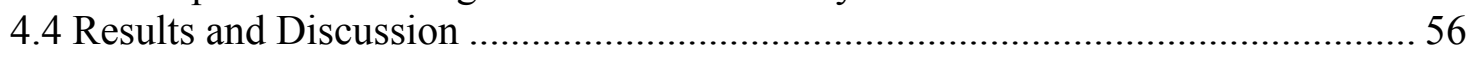

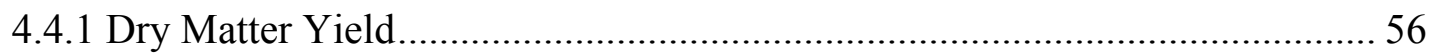

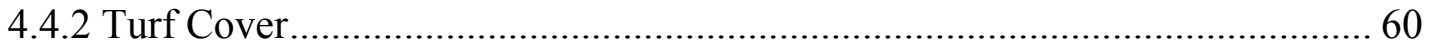

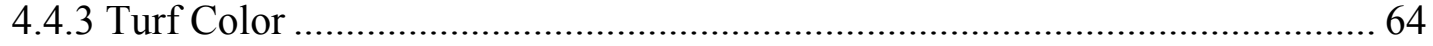

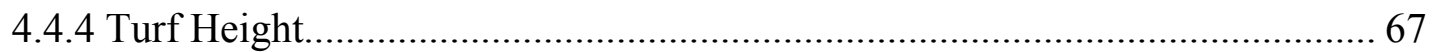

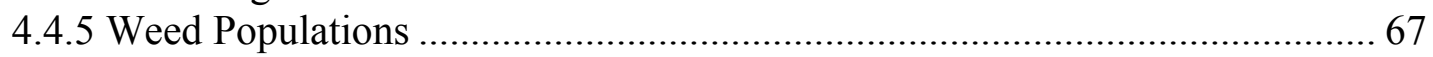

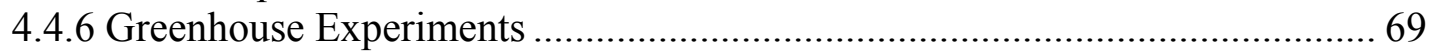

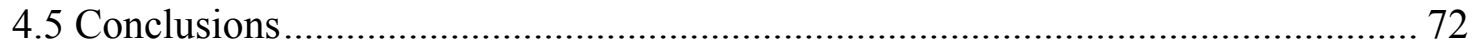

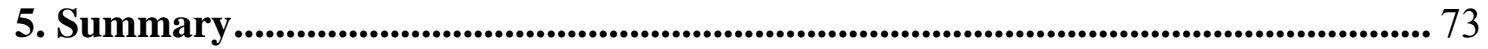

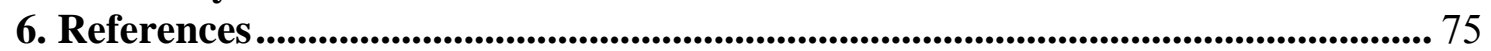




\section{List of Figures}

Fig. 2.1 Effect of compost extract on germination of grasses ...................................... 21

Fig. 2.2 Effect of compost extract on germination of broadleaves ................................. 22

Fig. 3.1 Effect of incorporating composted poultry litter into top $16 \mathrm{~cm}$ of subsoil on total percent water content $\left(\theta_{T}\right)$ by volume for $\bullet$ sodded compost; o sodded fertilizer; $\boldsymbol{\nabla}$ seeded compost; and $\nabla$ seeded fertilizer plots. 35

Fig. 3.2 Effect of incorporating composted poultry litter into top $16 \mathrm{~cm}$ of subsoil on organic matter for $\bullet$ sodded compost; o sodded fertilizer; $\mathbf{\nabla}$ seeded compost; and seeded fertilizer plots.

Fig. 3.3 Effect of incorporating composted poultry litter into top $16 \mathrm{~cm}$ of subsoil on available water, $A_{v}$ for $\bullet$ sodded compost; o sodded fertilizer; $\boldsymbol{\nabla}$ seeded compost; and $\nabla$ seeded fertilizer plots. 38

Fig. 3.4 Effect of incorporating composted poultry litter into top $16 \mathrm{~cm}$ of subsoil on soil bulk density for $\bullet$ sodded compost; o sodded fertilizer; $\mathbf{\nabla}$ seeded compost; and seeded fertilizer plots.

Fig. 3.5 Effect of incorporating composted poultry litter into top $16 \mathrm{~cm}$ of subsoil on soil $\mathrm{pH}$ for $\bullet$ sodded compost; o sodded fertilizer; $\mathbf{\nabla}$ seeded compost; and $\nabla$ seeded fertilizer plots

Fig. 3.6 Effect of incorporating composted poultry litter into top $16 \mathrm{~cm}$ of subsoil on cation exchange capacity (CEC) for $\bullet$ sodded compost; o sodded fertilizer; $\boldsymbol{\nabla}$ seeded compost; and $\nabla$ seeded fertilizer plots 45

Fig. 4.1 Effect of incorporating composted poultry litter into top $16 \mathrm{~cm}$ of subsoil on Kentucky bluegrass clipping yield (dry matter) for $\bullet$ sodded compost; o sodded fertilizer; $\nabla$ seeded compost; and $\nabla$ seeded fertilizer plots.

Fig. 4.2 Effect of incorporating composted poultry litter into top $16 \mathrm{~cm}$ of sunsoil on seeded Kentucky bluegrass cover for $\bullet$ April - seeded, compost; o April- fertilizer;

$\checkmark$ Sept. - seeded, compost; and $\nabla$ Sept. - fertilizer.

Fig. 4.3 Effect of incorporating composted poultry litter into top $16 \mathrm{~cm}$ of subsoil on Kentucky bluegrass seedling density.

Fig. 4.4 Effect of incorporating composted poultry litter into top $16 \mathrm{~cm}$ of subsoil on Kentucky bluegrass color $\bullet$ sodded compost - May; o sodded fertilizer - May; $\mathbf{v}$ seeded compost - May.; and $\nabla$ seeded fertilizer - May.

Fig. 4.5 Effect of incorporating composted poultry litter into top $16 \mathrm{~cm}$ of subsoil on

Kentucky bluegrass color $\bullet$ sodded compost - September; o sodded fertilizer September; $\nabla$ seeded compost - September; and $\nabla$ seeded fertilizer - September .. 66

Fig. 4.6 Effect of incorporating composted poultry litter into subsoil on Kentucky bluegrass root depth 
Fig. 4.7 Correlation analysis between turfgrass root depth and dry clipping weight 71

\section{List of Tables}

Table 1.1 Yield responses of vegetables, grains, fruits, forage, and turf to additions of various organic wastes. ................................................................................. 7

Table 3.1. Chemical characteristics of CPL used in this study.................................... 30

Table 3.2 Properties of subsoil used in this study...

Table 3.3. Analysis of variance for soil organic matter (OM), $\mathrm{pH}, \mathrm{CEC}$, bulk density, available water (AW), and mineral nutrient content............................................ 33

Table 3.4. Effect of different treatments on percent (by weight) of water held by subsoil

Table 3.5 Effect of incorporating composted poultry litter into top $16 \mathrm{~cm}$ of subsoil on soil mineral nutrient content of seeded and sodded plots ..................................... 43

Table 4.1 Precipitation recorded from May to September in 2004 ................................. 53

Table 4.2 Analysis of variance for dry matter, seedling height, visual color rating, and total weed count 58

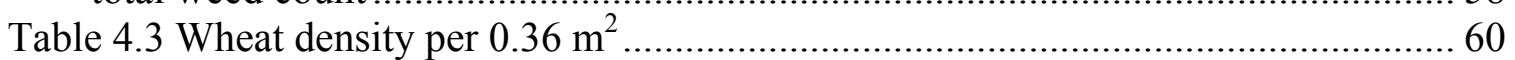

Table 4.4 Effect of different treatments on seeded and sodded turf height ......................67

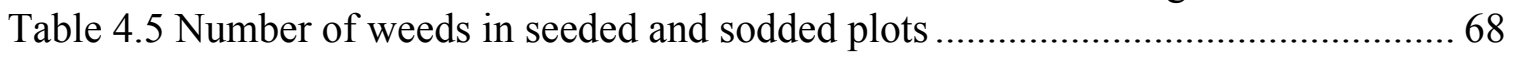

Table 4.6 Total number of manually seeded weed species.......................................... 69

Table 4.7 Effect of different treatments on dry clippings weight (greenhouse experiments) 


\section{Nomenclature}

$\begin{array}{ll}\text { AW } & \text { Available water } \\ \text { CB } & \text { Composted biosolids } \\ \text { CEC } & \text { Cation exchange capacity } \\ \text { CGW } & \text { Composted green waste } \\ \text { CPL } & \text { Composted poultry litter } \\ \text { C10 } & 10 \% \text { compost } \\ \text { C20 } & 20 \% \text { compost } \\ \text { C40 } & 40 \% \text { compost } \\ \text { KB } & \text { Kentucky bluegrass } \\ \text { LOI } & \text { Loss on ignition } \\ \text { MSW } & \text { Municipal sewage waste } \\ \text { OM } & \text { Organic matter } \\ \text { PL } & \text { Poultry litter } \\ \text { PR } & \text { Perennial ryegrass } \\ \text { SS } & \text { Sewage sludge } \\ \text { YT } & \text { Yard trimmings } \\ & \\ A_{v} & \text { Available water } \\ C_{w} & \text { Rock fragment } \\ \rho_{b} & \text { Bulk density } \\ \rho_{w} & \text { Density of water } \\ \theta_{T} & \text { Total water content }\end{array}$




\section{Introduction}

Establishing turfgrass in a suitable medium is paramount to its vigor and ability to tolerate pests. During construction disturbance, topsoil is often either lost or mixed with subsoil which is often high in clay and low in organic matter and nutrients (Landschoot and McNitt, 1994b). Turfgrasses established on such soils are weak and more prone to pests and diseases. Furthermore heavy equipments may compact the soil, making the conditions unfavorable for turfgrass establishment and growth (Loschinkohl and Boehm, 2001). Amending these disturbed soils with organic wastes (compost) can improve the fertility and physical and chemical properties of soil, providing a suitable seed-bed for turfgrass.

An increasing urban waste stream and restrictions on the methods of waste disposal have fueled resurgence in the use of composted organic wastes, as useful amendments in turfgrass management (Schumann et al., 1993). Composts can be used during turfgrass establishment as topdressing on already established turf or slow-release fertilizers (Landschoot and McNitt, 1994b). Various kinds of organic wastes like biosolids, municipal sewage, poultry litter (PL), sewage sludge (SS), and yard trimmings (YT) have been used as amendments in turf. Turfgrass establishment is significantly enhanced by the incorporation of composted biosolids into disturbed soil (Loschinkohl and Boehm, 2001). Compost helped turf to establish faster with improved density, growth, color (Gentilucci et al., 2001; Strange et al., 1998) and with a better rooting system (Landschoot and McNitt, 1994a). Various compost and organic materials helped in rapid healing of damaged turf, dollar spot suppression, and thatch reduction (Dinelli, 1999). Compost has been shown to be an effective and safe nutrient source and to 
increase yield of tall fescue (Kiemnec et al., 1987; Rasnake and Murdock, 2002). Municipal solid waste has shown to increase the root mass of St. Augustinegrass (Chandran, 1993).

Poultry litter has been used as a soil amendment to increase soil organic matter and to improve fertility and soil tilth (Gao and Chang, 1995; Eghball, 2002; Nyakatawa et al., 2001). Applications of PL to fields could reduce synthetic fertilizer inputs and improve the physical and chemical properties of soils. However, it can be a potential source of environmental contamination due to improper disposal and excessive use. Such a fate of PL can cause water pollution due to nitrate leaching into groundwater causing health problems, enrichment of water bodies resulting in eutrophication, production of phytotoxic substances, air pollution, and emission of ozone depleting gases (Kelleher et al., 2002; Tyson and Cabrera, 1993). Accumulation and increased mobility of $\mathrm{P}$ in soils were observed following the application of non-composted poultry manure (Vadas et al., 2004).

The environmental problems associated with the application of raw PL may be mitigated by composting. Composting PL can provide a beneficial alternative method for handling litter due to nutrient-content immobilization and reduction in pathogens and weed seeds, and it is easier to handle, store, transport, and apply compared to noncomposted organic materials (Millner et al., 1998). The composting process converts the highly mobile nitrate in the litter to slow releasing nutrients and produces humus that can be used as a source of organic materials (Paul and Clark, 1996).

Turfgrasses are often established in poorly prepared and compacted soil especially in urban landscape and residential settings. When predisposed to adverse growing 
conditions, the turf fails to establish properly allowing weeds to emerge in bare spots. Of all the environmental contaminants, pesticides used to control pests such as insects and weeds have been widely criticized due to their negative impact on the environment (Connell, 1997). Negative effects associated with the use of pesticides on the environment and human health has been well documented (Ross and Lembi, 1999). Due to rising environmental and public health concerns, landscape managers and homeowners are seeking alternative strategies for pest management in the landscape in an attempt to reduce pesticide application in the U.S.

\subsection{An Overview of Composting Industry}

Compost is a heterogeneous mixture of organic matter, which contains indigenous bacteria and fungi. With favorable temperature, moisture, and oxygen levels, these microorganisms multiply and aerobically decompose the carbon substrate releasing carbon, nitrogen, and other nutrient elements. The complex organic molecules in wastes are converted in compost through microbial activity. The resultant compost can be used as a soil conditioner and fertilizer (Poincelot, 1974).

Organic wastes are increasingly composted today and used as soil conditioners because of waste disposal problems and increases in fertilizer costs (Larney and Janzen, 1996; Poincelot, 1974). A full range of organic residuals - from municipal biosolids, yard trimmings, and sewage and brewery sludges to poultry litter is composted. The practice of composting, especially in agriculture and its application in the U.S. on a

commercial scale did not occur until the middle of the $20^{\text {th }}$ century (Stofella and Kahn, 2001). 
There are many commercial systems for composting which can be classified as open or in-vessel. Open systems include turned windrows, passively aerated static piles, and forced aerated static piles and bins (Stofella and Kahn, 2001). In-vessel systems are engineered, provide homogeneity and odor control (Gouin, 1998) and include agitated beds, modular aerated containers and tunnels, aerated-agitated containers, silo or tower reactors, and rotating drums (Stofella and Kahn, 2001). The type of system used for composting influences the time of composting, space required, expense, and kind of feedstock(s) and waste(s) to be composted. Biosolid feedstocks like animal manures and wood waste require less blending to produce uniform compost. Variable feedstocks, such as MSW, YT, and waste from processing plants will produce highly variable compost unless subjected to horizontal mixing (Gouin, 1998).

Important parameters affecting composting are temperature $\left(40^{\circ} \mathrm{C}\right.$ to $\left.71^{\circ} \mathrm{C}\right)$, moisture ( $40 \%$ to $60 \%$ ), amount of oxygen, $\mathrm{C} / \mathrm{N}$ ratio (26 to 35 ), and the rate of organic matter decomposition (Poincelot, 1974). In order to produce quality compost, the substrate should remain aerobic to generate minimal odors (Gouin, 1998). Chemicals released during the initial stages of composting have beneficial effects in reducing the levels of microorganisms that cause plant diseases (McConnell et al., 1993). Factors that may affect the usefulness of compost products are composition and quality of feedstock, consistency of product properties, and safety from harmful ingredients such as weed seeds, pathogens, pesticide residuals, or toxic metals (Shiralipour et al., 1993).

In Western Europe and North America, research on compost incorporation to enhance crop yield is occurring more frequently as many industries and municipalities are adopting composting as a way to reduce organic wastes (Dick and McCoy, 1993). The 
landscaping industry is one of the largest sectors consuming compost, followed by nursery/horticultural applications, parks and athletic fields, golf courses, agriculture, and land reclamation/bioremediation operations (Goldstein and Steuteville, 1995). In many states, the agricultural sites are located several miles away from compost sources. Thus, transportation costs affect the size of the agricultural market (Shiralipour et al., 1993).

\subsection{Compost as a Soil Conditioner}

Mature compost; low in viable weed seeds, heavy metals, and other phytotoxic contaminants; can be used beneficially as a slow release fertilizer and soil conditioner in the production of field crops, fruits, vegetables, forages, nursery crops, and ornamentals (Darmody et al., 1983). The nursery industry uses peat extensively as a soil-less potting media due to its organic composition and high water holding capacity. Compost made from bark and SS could serve as a viable alternative substrate for otherwise expensive peat in the production of containerized perennials while maintaining sufficient plant growth, development, and quality (Pinamonti et al., 1997; Wilson and Stofella, 2003). Composts can also reduce the costs of establishing golf courses and parks and the costs of home landscape maintenance and management (Shiralipour et al, 1993).

Studies were conducted to compare the capacity of different types of composts as fertilizers. In the experiment conducted by Larney and Janzen (1996), the best compost amendment was found to be that of hog manure, followed by poultry manure and alfalfa hay. All of these amendments resulted in significantly higher yields of wheat. Cattle manure containing wood shavings was not as effective in restoring eroded soil as other forms of cattle manure (fresh, old, and composted). This was probably due to its low $\mathrm{N}$ content and high $\mathrm{C} / \mathrm{N}$ ratio (Larney and Janzen, 1996). 
The combined application of compost and fertilizer has been investigated to see if the combination improved their effectiveness. Results obtained from various studies indicated that these materials are more efficient when applied together than from separate applications of each. The application of compost as fertilizer on crops has generally yielded positive results (Table 1.1). Increases in crop yield is attributed to the ability of compost to provide $\mathrm{N}$ over an extended period of time, as opposed to the quick release of nutrients from inorganic fertilizers (Ozores-Hampton and Bryan, 1993). The greenhouse industry is a unique fit to utilize sewage refuse compost because heavy metals do not pose serious problems in the production of some ornamental plants (Sanderson, 1980). When used as mulch, sewage refuse compost controls weeds, resists erosion and increases soil nutrients (Sanderson, 1980). Sewage sludge serves as an organic fertilizer when applied at a rate less than $80 \mathrm{MT} \mathrm{ha}^{-1}$. At rates above $80 \mathrm{MT} \mathrm{ha}^{-1}$ it has acted as a soil conditioner (Bevacqua and Mellano, 1993b). The health and environmental hazards associated with the use of compost include a buildup of metals such as $\mathrm{As}, \mathrm{Cd}, \mathrm{Cu}, \mathrm{Mn}$, $\mathrm{Ni}$, and Zn to toxic levels (Bevacqua and Mellano, 1993a; Giusquiani et al., 1995; Gupta and Charles, 1999; Paino et al., 1996), and an increase in the accumulation of $\mathrm{Na}, \mathrm{K}$ (McDonald et al., 2004) and P (Nyakatawa et al., 2001). 
Table 1.1 Yield responses of vegetables, grains, fruits, forage, and turf to additions of various organic wastes.

\begin{tabular}{|c|c|c|c|c|}
\hline Crop & $\begin{array}{c}\text { Compost } \\
\text { Type } \\
\end{array}$ & Rate & Effect & Citation \\
\hline $\begin{array}{l}\text { Sorghum, } \\
\text { Bermudagrass, } \\
\text { Corn }\end{array}$ & $\mathrm{MSW}+\mathrm{SS}$ & $\begin{array}{l}80,112,143 \\
\text { t/ha }\end{array}$ & Positive yield response & Mays et al., 1973 \\
\hline Tall fescue & $\mathrm{SS}$ & $\begin{array}{l}44.8,89.6 \\
134.4 \mathrm{t} / \mathrm{ha}\end{array}$ & $\begin{array}{l}\text { Linear increase in yield } \\
\text { with increasing rates of } \\
\text { SS }\end{array}$ & Sikora et al., 1980 \\
\hline KB, Tall fescue & SS & $\begin{array}{l}90,180,360 \\
720 \mathrm{t} / \mathrm{ha}\end{array}$ & $\begin{array}{l}\text { Improved establishment } \\
\text { and appearance }\end{array}$ & Angle et al., 1981 \\
\hline Tall fescue & SS & $\begin{array}{c}110,220,440 \\
880 \mathrm{Kg} \mathrm{N} / \mathrm{ha}\end{array}$ & $\begin{array}{l}\text { Linear increase in yield } \\
\text { with increasing rates of } \\
\text { SS }\end{array}$ & $\begin{array}{c}\text { Kiemnec et al., } \\
1987\end{array}$ \\
\hline Tall fescue & SS & $\begin{array}{c}45,90,135 \\
\mathrm{Mg} / \mathrm{ha} \\
\text { (greenhouse) } \\
60,120,240 \\
\mathrm{Mg} / \mathrm{ha} \text { (field) }\end{array}$ & $\begin{array}{l}\text { Linear increase in yield } \\
\text { with increasing rates of } \\
\text { SS }\end{array}$ & Tester, 1989 \\
\hline Broccoli & $\begin{array}{c}\text { Plant and } \\
\text { animal wastes }\end{array}$ & $\begin{array}{c}3,7.5,30 \\
\mathrm{Mg} / \mathrm{ha}\end{array}$ & $\begin{array}{l}\text { Increase in yield by } 86 \text { to } \\
495 \%\end{array}$ & $\begin{array}{l}\text { Buchanan and } \\
\text { Gliessman, } 1991\end{array}$ \\
\hline $\begin{array}{l}\text { Onion, Lettuce, } \\
\text { and Turf }\end{array}$ & $\mathrm{SS}$ & $37,74 \mathrm{t} / \mathrm{ha}$ & $\begin{array}{l}\text { Increase in yield, Onion: } \\
46 \text { to } 50 \% \text {, Lettuce: } 56 \text { to } \\
137 \% \text {, Turf: } 235 \text { to } 700 \%\end{array}$ & $\begin{array}{l}\text { Bevacqua and } \\
\text { Mellano, 1993b }\end{array}$ \\
\hline Tomato & MSW & $25,50 \mathrm{t} / \mathrm{ha}$ & $\begin{array}{c}\text { Increase in yield by } 23 \text { to } \\
38 \%\end{array}$ & Maynard, 1993 \\
\hline Snap beans & MSW & 90 t/ha & Increase in yield by $22 \%$ & $\begin{array}{l}\text { Ozores-Hampton } \\
\text { and Bryan, } 1993\end{array}$ \\
\hline $\begin{array}{l}\text { Tall fescue, } \mathrm{PR}+ \\
\text { KB }\end{array}$ & $\begin{array}{l}\text { Waste water } \\
\text { sludge }\end{array}$ & $\begin{array}{c}4850,9700 \\
\mathrm{Kg} / \mathrm{ha}\end{array}$ & $\begin{array}{c}\text { Increase in yield } \\
\text { Tall fescue: } 52 \text { to } 63 \% \\
\text { PR + KB: up to } 37 \%\end{array}$ & $\begin{array}{c}\text { Schuman et al., } \\
1993\end{array}$ \\
\hline Bermudagrass & PL & $\begin{array}{c}5.6,11.2,22.4 \\
\mathrm{Mg} / \mathrm{ha}\end{array}$ & $\begin{array}{c}423 \% \text { increase in yield } \\
56 \% \text { better quality }\end{array}$ & Wood et al., 1993 \\
\hline $\mathrm{KB}$ & Biosolids & $6.2 \mathrm{cu} \mathrm{yds} /$ & $80 \%$ more turf cover & Landschoot and \\
\hline
\end{tabular}


$1000 \mathrm{sqft}$

\begin{tabular}{|c|c|c|c|c|}
\hline Tomato, Squash & MSW & $24,48 \mathrm{t} / \mathrm{ha}$ & $\begin{array}{l}\text { Increase in yield, } \\
\text { Tomato: } 10 \text { to } 65 \% \text {, } \\
\text { Squash: } 4 \text { to } 30 \%\end{array}$ & $\begin{array}{c}\text { Ozores-Hampton } \\
\text { et al., } 1994\end{array}$ \\
\hline Bell pepper & CGW & $\begin{array}{c}17,34 \mathrm{t} / \mathrm{ha}+ \\
\text { fertilizer }(168 \\
\mathrm{Kg} / \mathrm{ha}) \\
20 \mathrm{Mg} / \mathrm{ha}\end{array}$ & $11 \%$ increase in yield & Hartz et al., 1996 \\
\hline
\end{tabular}

Increase in yield

Hog manure: 15 to $52 \% \quad$ Larney and

Poultry manure: 12 to Janzen, 1996

$$
48 \%
$$

Improved groundcover Norrie and

KB: 67 to $79 \%$, KB+PR: Gosselin, 1996 $<89 \%$

$1 / 4,1 / 2$ and 1 inch

thickness

$($ linch $=9.2 \mathrm{lb}$

$\mathrm{N} / 1000 \mathrm{sqft}$ )

Improved turf color and
quality

Strange et al., 1998

Turf color rating Increased: 20 to $45 \%$

Clipping yields

increased: 21 to $106 \%$

Increased cover, KB: 310\%, PR: 6 to $8 \%$

Increased yield, KB: 5.5

to $10.5 \%$, PR: $2 \%$
Garling and

Boehm, 2001
$130 \mathrm{~m}^{3} / \mathrm{ha}$

Loschinkohl and

Boehm, 2001

$\mathrm{KB}, \mathrm{PR}$

SS

Raw PL,

Corn

Different aged

PL

$8.9,59,64,68.7$
$\mathrm{Mg} / \mathrm{ha}$

$30 \%$ increase in yield and biomass in raw PL than different aged PL

Tall fescue

PL

$2,4 \mathrm{t} / \mathrm{ha}$

Increase in yield, 25 to 209\%

Cooperband et al., 2002

Rasnake and Murdock, 2002

$\mathrm{CB}=$ Composted biosolids; $\mathrm{CGW}=$ Composted green waste; $\mathrm{MSW}=$ Municipal Sewage;

$\mathrm{KB}=$ Kentucky bluegrass; $\mathrm{PL}=$ Poultry litter; $\mathrm{PR}=$ perennial ryegrass; $\mathrm{SS}=$ Sewage sludge;

$\mathrm{YT}=$ Yard trimmings 
Composting can reduce the environmental problems associated with the application of raw PL. Composting converts the soluble nutrients to more stable organic forms, thereby reducing their susceptibility to loss when applied to crops (Tiquia and Tam, 2002). By utilizing CPL for crops such as turfgrasses, which are not directly, consumed by man, possible health hazards such as lead-toxicity can be eliminated (Angle et al., 1981). There are few other problems of using composts as a source of mineral nutrients for crop growth. Microorganisms in immature compost require nutrients to form mature compost. This depletes the soil of available nutrients; especially N. Compost is a dilute source of $\mathrm{N}, \mathrm{P}$, and $\mathrm{K}$ as compared to the mineral fertilizer. Compost alone, therefore, may not be able to meet the crop requirement for major nutrients (Dick and McCoy, 1993).

\subsection{Use of Composted Solid Wastes in Turfgrass Industry}

Turfgrasses in golf courses, athletic fields, and other high traffic areas are usually grown on soils modified through the addition of both organic and inorganic amendments (Nelson, 1996). This helps in minimizing soil compaction and plant stress, and improves plant-soil relationship for the better growth of turfgrass. Today most golf course turfgrasses are commonly grown using artificial growth media similar to those used in horticulture and nursery industries (Nelson, 1996). Turfgrass managers are using natural organic fertilizers for maintaining quality turf, because they have high nutrient content, are readily decomposed, support high level of microbial populations and, reduce incidences and severity of some turfgrass diseases, thatch buildup, soil compaction, nitrate and pesticide movement (Nelson, 1996). 
Composts have been used as soil amendments during turfgrass establishment. Replenishing disturbed soils with compost can provide better turf growth, which facilitates the establishment of turfgrass in subsoil with a minimal weed seed bank. Due to the variability in compostable materials, it is important to determine the composts suitable for use on turf. Landschoot and McNitt (1994b) have refined the basic guidelines for evaluating the suitability of compost for use on turf as follows:

Appearance: The end product should resemble dark topsoil, should be friable, and should be free of large stones and large pieces of wood, trash, and other objectionable objects.

Odor: Good quality and mature compost should have earthy aroma and should not emit offensive odors, such as strong ammonia or sulfur smell.

Moisture content: Moisture contents between $30 \%$ and $50 \%$ are usually ideal. Wet composts (greater than $60 \%$ moisture content) tend to form clumps and do not spread evenly when applied as topdressings. They are also heavy and difficult to handle. Dry composts (less than $20 \%$ moisture content) are easy to handle and spread easily, but may produce excessive dust.

Carbon to nitrogen ratio: The $\mathrm{C} / \mathrm{N}$ ratio of compost should fall below 30:1. If it is above 30:1, soil microorganisms can immobilize nitrogen making it unavailable to the turf.

Nutrients: Composts generally contain lower amounts of plant nutrients than fertilizers, and most nitrogen is in the organic form and slowly available to turf. Animal manure composts have higher plant nutrients than yard waste composts. 
$p H$ : Favorable $\mathrm{pH}$ for turf root growth is between 6.0 and 8.0. Extremes in $\mathrm{pH}$ may result in nutrient deficiency and toxicity problems.

Metals: Composts made from sewage sludge often have higher metal concentrations than those made from other sources.

Soluble salts: Excessive soluble salts can cause injury to turf by reducing water absorption, by toxicity, or by a combination of the two. Sodium containing salts containing are more toxic to turfgrasses than potassium salts.

Research on turfgrass has shown beneficial effects of compost as a soil amendment and topdressing (Table 2.1). Turf color and quality are correlated with $\mathrm{N}$ uptake. Darker turf color and higher yields are usually an indication of higher inorganic N (Landschoot and Waddington, 1987).

Currently, homeowners are facing a challenge for establishing lawn on disturbed soil, as a result of construction during which topsoil is often removed or covered with excavated subsoil. Amending these disturbed soils with compost may enhance turfgrass establishment and growth because of additions of $\mathrm{N}$ and $\mathrm{P}$ to the soil (Loschinkohl and Boehm, 2001).

\subsection{Effect of Compost on Suppression of Turfgrass Diseases}

The turfgrasses, especially on golf courses, represent the highest level of plant management in any agricultural or horticultural commodity (Nelson, 1996). Proper turfgrass management involves mechanical, chemical, physical, and biological manipulations to achieve weed-free and disease-free turfgrass (Nelson, 1996). Because of this high degree of manipulation and rigorous physical demands placed on turfgrass, considerable effort goes toward the maintenance of soil conditions to maximize turfgrass 
growth and survival, and towards the management of pest outbreaks. In recent years, greater emphasis has been placed on developing alternative biological based methods for pest control in turfgrasses.

Of all the organic materials used, composted amendments have proven to be the most effective in reducing the severity of diseases in turfgrasses. The ability of compost to suppress diseases depends on factors such as microbial activity and population dynamics, nutrient concentrations, and other chemical and physical properties (Boulter et al., 2002). Compost suppressed dollar spot (Boulter et al., 2002; Nelson and Craft, 1992) and brown patch, typhula blight and red thread of turfgrasses (Nelson, 1996); phythium root rot and damping off of ornamental and nursery crops (Hoitink and Boehm, 1999). It also reduced the severity of leaf rust disease of turfgrass (Loschinkohl and Boehm, 2001).

Compost extracts have shown to inhibit Botrytis cinerea Pers. Fr. (McQuilken et al., 1994), downy grape mildew (Uncinula necator) (Weltzien, 1991), and pythium root rot on creeping bentgrass turf (Nelson, 1996). The ability of compost extracts to suppress diseases is believed to be mainly due to the number and the quantity of living microbes (Weltzien, 1991). Compost water extracts are considered to have the potential for biological control, especially in organic and low input agricultural systems (McQuilken et al., 1994). Although the exact mechanisms by which composts suppress turfgrasses diseases are unknown, a number of bacterial and fungal species have been known as agents of the control (Boulter et al., 2000).

One of the greatest hindrances in the use of organic amendments for turfgrass disease control is the inconsistent performance from site to site, batch to batch and year to year (Nelson, 1996). The use of composts as plant disease suppressants is not likely to 
replace the use of commercial fungicides. However, multiple applications of compost may reduce the incidence and the severity of disease levels and may reduce the use of fungicides.

\subsection{Changes in Soil Properties Due to Various Solid Wastes Compost}

Physical Changes

Researchers have shown that compost improved the physical properties of soils. Compost increased organic matter content, total porosity, permeability to air and water, water holding capacity, and enhanced aggregation of soil particles, however reduced bulk density, penetration resistance, and surface crusting and compaction of soils. (Aggelides and Londra, 2000; Giusquiani et al., 1995; Landschoot and McNitt, 1994a; McConnell et al., 1993; Warren and Fonteno, 1993)

\section{Chemical changes}

Soil pH (Aggelides and Londra, 2000), available P, and exchangeable K, Mg, and Ca increased with increased applications of animal manures to soil (Warren and Fonteno, 1993; Clark et al., 1998). Compost application rates of $3.75^{*} 10^{4} \mathrm{Kg} \mathrm{ha}^{-1}$ to $7.5^{*} 10^{4} \mathrm{Kg}$

$\mathrm{ha}^{-1}$ increased the CEC by at least $10 \%$, which in turn increased the ability of the soils to hold added mineral fertilizer elements, increasing the plant uptake of these elements (Epstein et al., 1976; McConnell et al., 1993). Compost also improved the ability of the soil to bind toxic metals and make them less available to plants (Epstein et al., 1976; Dick and McCoy, 1993).

\section{Biological changes}

The application of compost to soils adds not only organic matter but also living organisms (Dick and McCoy, 1993). Incidences of increases in soil enzymatic activities 
(arylsulphatase, dehydrogenase, phosphodieterase, and phosphomonoesterase) in soils amended with compost were reported by Perucci (1990) and Giusquiani et al. (1995). The increase in enzymatic activities may be due to the increase of pore space and due to organic substances added to soil (Perucci, 1990).

There is much to be understood about the efficient use of organic amendments in turfgrass management, but it is clear that the benefits of such amendments outweigh any negative effect of their use. Organic amendment is likely to be the key element for sustainable maintenance of turfgrass quality and overall growth of turfgrass. Several studies have investigated the effects of different kinds of composts on turfgrass growth and establishment. However, limited information is available on the effect of CPL on soil physical and chemical properties, weed control, and turfgrass establishment which is otherwise known to cause environmental problems due to mismanagement.

The objectives of this research are to evaluate (a) changes in soil physical and chemical properties of disturbed soils as a result of using CPL as a soil amendment on disturbed soils; and (b) effects of CPL incorporation into subsoil typical of construction sites on the establishment and subsequent growth attributes of Kentucky bluegrass and control of the weed population. It is hypothesized that the total absence or limited presence of a weed seed bank will enhance establishment of turfgrass considerably. Partial management of weeds could be achieved by providing optimum conditions for turf growth by improving its competitive ability (Chandran, 2003; Watchke, 1994). In this study, we propose an integrated approach to manage weeds in turf by encompassing a novel strategy; establishing turfgrass in CPL amended subsoil that has the potential to minimize weed emergence and competition during early critical stages of lawn 
establishment by minimizing the weed seed bank and improving soil physical and chemical properties. 


\section{Laboratory Experiments: Suppression of Weed Seeds Germination by Compost Extract}

\subsection{Abstract}

A series of laboratory experiments were conducted at West Virginia University to observe the effect of poultry litter (PL) compost extract on the germination of 12 weed species. The compost utilized for the experiments was derived from PL with wood chips and cardboard as a primary source of carbon with a ratio of 2:2:2 $\left(\mathrm{N}, \mathrm{P}_{2} \mathrm{O}_{5}, \mathrm{~K}_{2} \mathrm{O}\right)$ (Borderline LLC, Baker, WV). Compost extracts at three different concentrations (compost:water w/w) 1:8 (low), 1:5 (medium), and 1:2 (high) were compared to distilled water (control) for weed seed germination. Petri dishes $(150 \times 15 \mathrm{~mm})$ were lined with filter paper and $8 \mathrm{ml}$ of compost extract was pipetted into each petri dish. Seeds were placed and dishes were sealed with parafilm. Each treatment was replicated four times and was arranged in completely randomized design, and was incubated at $27^{\circ} \mathrm{C}\left(+/-2^{\circ}\right.$ $\mathrm{C})$, and $12 \mathrm{~h}$ daylength inside the growth chamber. Seeds were considered germinated when radicles emerged from the seed coat. The highest concentration inhibited germination in johnsongrass, small flower morningglory, and ivyleaf morningglory by $>$ $90 \%$ and crabgrass, green foxtail, pigweed, and ragweed germination by $>85 \%$, while medium concentration inhibited germination in giant foxtail by $90 \%$. More than $50 \%$ inhibition of germination was observed in green foxtail, yellow foxtail, johnsongrass, tall morningglory, common lambsquarters, and ragweed by medium concentration, while low concentration (1:8) inhibited germination by $70 \%$ in giant foxtail as compared to control. In these experiments, all the weed species were found to be sensitive to compost extract except barnyardgrass. 


\subsection{Introduction}

Weed growth suppression is an important attribute of some surface-applied compost. Compost applied to soils may suppress weeds due to the physical barrier of the compost or due to phytotoxic compounds like volatile fatty acids or ammonia generated by microbes in the composting process. High $\mathrm{CO}_{2}$ levels resulting from biological activity and high temperatures in composts can decrease germination of weeds below the soil surface (Shiralipour et al., 1991; Ozores-Hampton et al., 1999). The process of composting generates heat to levels sufficient to kill most viable weed seeds (OzoresHampton et al., 1996).

Municipal solid waste reduced the percentage of weed dry mass and weed cover (Ozores-Hampton et al., 2001) and thus, has potential as viable mulch for weed control in vegetable crop alleys. Stratton and Reichcigl (1998) observed significant suppression of broadleaf and annual grass weeds by using organic mulches, wood products, and composts as soil amendments. Weed control usually improves as the thickness of mulch increases. However, the extent to which weeds will be controlled depends on compost type, weed species and environmental conditions (Ozores-Hampton, 1998). Strange et al. (1998) reported that compost topdressing of $9.2 \mathrm{lb} \mathrm{N} / 1000 \mathrm{ft}^{2}$ was optimal for keeping summer annual weeds at $20 \%$ or less and winter weeds at lower percentages than the control or the fertilized plots of bermudagrass. Municipal solid waste applied at

$224 \mathrm{t} \mathrm{ha}^{-1}$ reduced weed growth in alleyways of bell pepper (Roe and Stofella, 1993). These experiments indicate the presence of water-soluble phytotoxic substances in the composting materials that have inhibitory effects on seed germination (Ozores-Hampton, 1998). 
It has been observed that the application of fresh town refuse compost to soils inhibits or causes irregularity in plant growth. This might be due to the presence of organic acids like acetic acid, propionic acid, isobutyric acid, butyric acid, and isovaleric acid (DeVleeschauwer et al., 1981) which are produced as a natural byproduct during the early stages of organic matter decomposition (Stofella and Kahn, 2001). The phytotoxic effect of the fresh compost could be attributed to acetic acid that was found in large concentrations (DeVleeschauwer et al., 1981). Ozores-Hampton et al. (1999) found that extracts from immature MSW and biosolids compost with acetic acid concentrations of 2424, 1790, and $1776 \mathrm{mg} \mathrm{kg}^{-1}$ delayed and reduced the germination percentage of important economic weeds like barnyardgrass [Echinochloa crus-galli (L.) Beauv.], common purslane [Portulaca oleracea L.], large crabgrass [Digitaria sanguinalis (L.) Scop], curly dock [Rumex crispus L.], dichondra [Dichondra carolinensis Michx.], ivyleaf morning-glory [Ipomoea hederacea L.], lovegrass [Eragrostis curvula], pigweed [Amaranthus retroflexus L.], wild mustard [Brassica kaber (DC) L.C. Wheeler], and wild radish [Raphanus raphanistrum L.]. Yard waste/biosolid compost, when applied at a 7.5 cm depth had the highest rate of weed suppression (Stoffella et al., 2000). These results suggest that immature compost can be utilized as an alternative biological method of weed control in crops (Ozores-Hampton et al., 1999; Stofella et al., 2000).

In this context, the objective of this study was to determine the effect of compost extract (made from CPL) on the germination of various weed species.

\subsection{Materials and Methods}

Weed seeds were obtained from Valley Seed Service, Fresno, California. Weed species used were annual ragweed [Ambrosia artemisiifolia (L.)], barnyardgrass 
[Echinochloa crus-galli (L.) Beauv.], common lambsquarters [Chenopodium album (L.)], giant foxtail [Setaria faberi Herrm.], green foxtail [Setaria viridis (L.) Beauv.], ivyleaf morningglory [Ipomoea hederacea (L.) Jacq.], johnsongrass [Sorghum halepense (L.) Pers.], large crabgrass [Digitaria sanguinalis (L.) Scop.], pigweed [Amaranthus hybridus (L.)], small flower morningglory [Jacquemontia tamnifolia (L.) Griseb.], tall morningglory [Ipomoea purpurea (L.)], and yellow foxtail [Setaria glauca (L.) Beauv.]. The compost utilized for the experiments was derived from poultry litter with wood chips and cardboard as a primary source of carbon with a ratio of 2:2:2 (N, $\left.\mathrm{P}_{2} \mathrm{O}_{5}, \mathrm{~K}_{2} \mathrm{O}\right)$ (Borderline LLC, Baker, WV). Compost extracts were prepared by adding 2, 5, and 8 parts of water (high, medium, and low concentrations, respectively) to each part of compost $(\mathrm{v} / \mathrm{v})$. Extracts are typically prepared by mixing one volume of compost with 5 to 10 vol. of water at temperatures $15^{\circ} \mathrm{C}$ to $20^{\circ} \mathrm{C}$ (Nelson, 1996; Boulter et al., 2000). After leaving the mixture undisturbed for a period of $5 \mathrm{~d}$ at a temp of $20^{\circ} \mathrm{C}$ it was handpressed and filtered using cheesecloth. The filtrate collected was used for subsequent germination tests.

Petri dishes $(150 \times 15 \mathrm{~mm})$ were lined with filter paper and $8 \mathrm{ml}$ of compost extract was pipetted into each petri dish. Seeds were placed in each petri dish, and dishes were sealed with parafilm. Each treatment was replicated four times and four petri dishes were considered as one replication. Petri dishes were arranged in completely randomized design, and were incubated at $27^{\circ} \mathrm{C}\left(+/-2^{\circ} \mathrm{C}\right)$, and $12 \mathrm{~h}$ daylength inside the growth chamber. Seeds were considered germinated when radicles emerged from the seed coat. Germinated seeds were counted after $5 \mathrm{~d}$ and were discarded. Subsequent counts were taken three times at $5 \mathrm{~d}$ intervals. Experiments were repeated four times. Data were 
subjected to analysis of variance and means were separated by LSD $(p=0.05)$. The results of all four bioassay experiments were found to be homogenous and were thus combined.

\subsection{Results and Discussion}

Composted poultry litter extract affected germination of the weed species tested (Figs. 2.1 and 2.2). Percentage germination was mostly reduced by the high concentration (1:2) of compost extract. This concentration inhibited the germination of giant foxtail, yellow foxtail, and common lambsquarters. This concentration also reduced the germination in johnsongrass, small flower morningglory, and ivyleaf morningglory by $>90 \%$ and crabgrass, green foxtail, pigweed, and ragweed germination by $>85 \%$ compared to the control. Medium concentration (1:5) inhibited germination in giant foxtail by $90 \%$. More than $50 \%$ inhibition in germination was observed in green foxtail, yellow foxtail, johnsongrass, tall morningglory, common lambsquarters, and ragweed by medium concentration, while low concentration (1:8) inhibited germination by $70 \%$ in giant foxtail. Interestingly, low concentration enhanced germination in common lambsquarters and ragweed by $25 \%$. In these experiments all the weed species were found to be sensitive to compost extract except barnyardgrass, which was most resistant to compost extract. The low weed seed germination by compost extract is most likely due to the increase in salinity caused by salts present in compost. Increase in salinity induces water stress which consequently decreases the water retention capacity of the seed (Kabir et al., 2004). A study done by Uhvits (1946) indicated that an increase in salt concentration decreased the rate of entry of water into the seed and that in turn retards germination. 


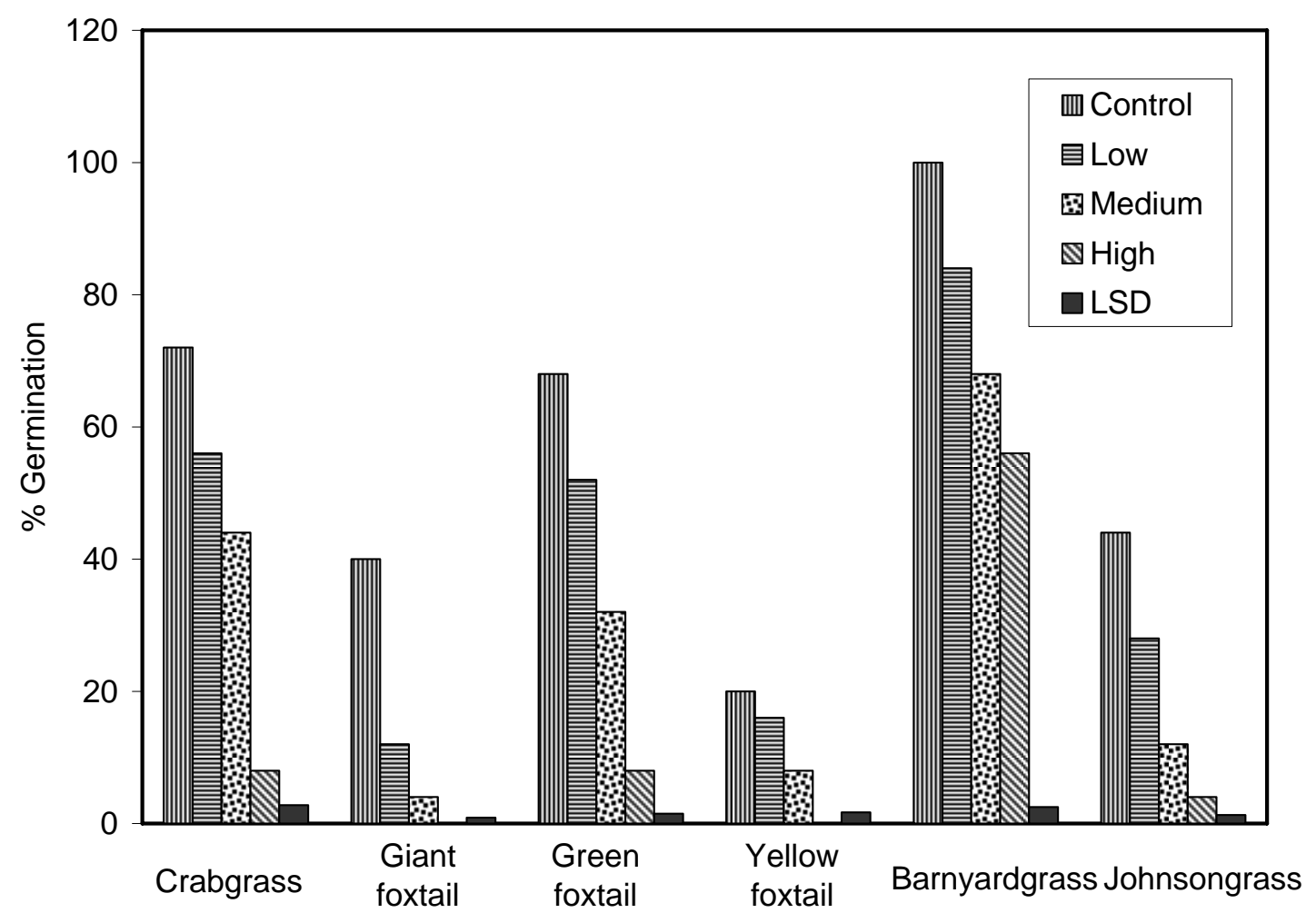

Fig. 2.1 Effect of compost extract on germination of grasses 


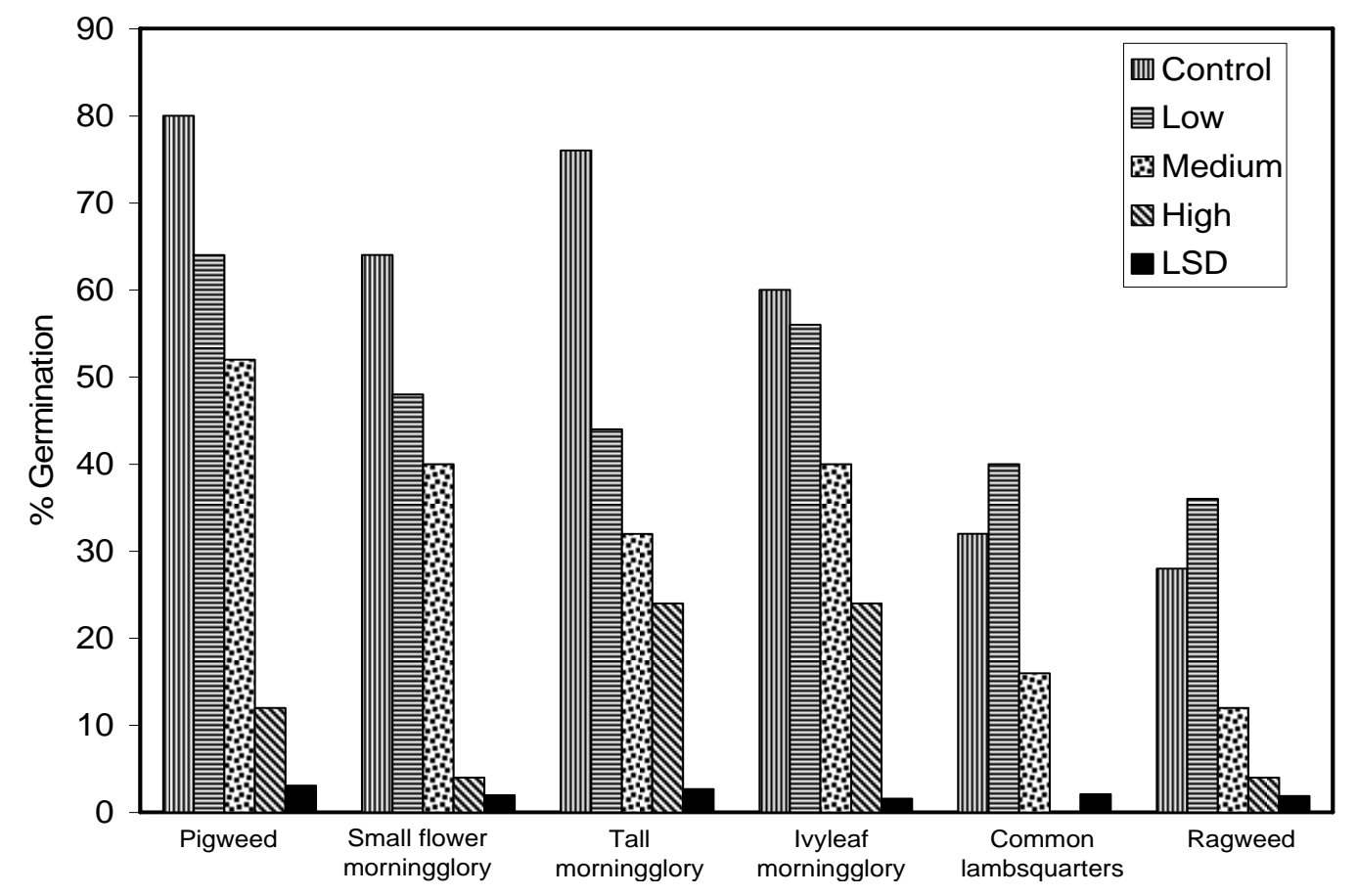

Fig. 2.2 Effect of compost extract on germination of broadleaves

This study also indicates the presence of water-soluble substances in the composting material that have inhibitory effects on seed germination. Previous studies by others indicated that the suppression of weed seed germination might be due to the presence of phytotoxic compounds such as acetic, propionic, and butyric acids, ammonia, ethylene oxide, and phenolic acides (DeVleeschauwer et al., 1981; Ozores-Hampton, 1998) in the compost or due to the presence of high concentrations of soluble salts. McDonald et al. (2004) determined the inhibitory effects of salts on barnyardgrss, green foxtail, large crabgrass and purslane. Germination of green foxtail and large crabgrass decreased whereas the germination of purslane and barnyardgrass was not affected by total salt concentration. High levels of soluble salts were observed to inhibit plant growth when a mixture of MSW and sandy soil was used to grow turnip (Chanysak et al., 1983). 
Bioassays of different compost maturities (three day-old, four week-old, eight week-old) indicated that eight week-old compost extract inhibited germination in ivyleaf morningglory (Ipomoea hederacea), barnyardgrass (Echinochloa crus-galli L.), and purslane (Potulaca oleracea) (Ozores-Hampton et al., 1999). Water extract prepared from 3 wk old YT inhibited germination of several perennial and annual weeds (Florida beggarweed, yellow nutsedge, ragweed) at temperatures over $60^{\circ} \mathrm{C}$ (Shiralipour and McConnell, 1991). In another study, extract from 8 week-old MSW inhibited seed germination and growth of 14 weed species, but not yellow nutsedge (Ozores-Hampton et

al., 1996). Extraction time as well as extraction temperature affects the suppressive ability of the final extract. Extraction times of 4 to $7 \mathrm{~d}$ maximized the suppressive activity of compost extracts but temperatures above $18.3^{\circ} \mathrm{C}$ to $21^{\circ} \mathrm{C}$ reduced the suppressive activity of the extract (Nelson, 1996).

\subsection{Conclusions}

Compost extract inhibited the germination of almost all weed species. Germination rate decreased with increasing rates of compost extract concentration. The highest concentration (1:2) inhibited germination in johnsongrass, small flower morningglory, and ivyleaf morningglory by $>90 \%$ and crabgrass, green foxtail, pigweed, and ragweed germination by $>85 \%$, while medium concentration (1:5) inhibited germination in giant foxtail by $90 \%$. More than $50 \%$ inhibition of germination was observed in green foxtail, yellow foxtail, johnsongrass, tall morningglory, common lambsquarters, and ragweed by medium concentration, while low concentration (1:8) inhibited germination by $70 \%$ in giant foxtail as compared to control. In this experiment, most sensitive weed species to compost extract were johnsongrass, small flower 
morningglory, ivyleaf morningglory, crabgrass, green foxtail, pigweed, and annual ragweed, however, barnyardgrass and common lambsquarters were found to be least sensitive to compost extract. Further experiments can be done to determine the effect of compost extract on turfgrass seeds. 


\section{Amending Subsoil with Composted Poultry Litter- I: Effects on Soil Physical and Chemical Properties}

\subsection{Abstract}

Environmental problems associated with the use of raw poultry litter (PL) can be mitigated by immobilizing nutrients, especially soluble P. Composting PL has been suggested as a means to stabilize $\mathrm{P}$ and convert highly mobile nitrate into slow release nutrients. Utilizing composted poultry litter for turfgrass establishment on disturbed soil is an environmentally desirable disposal method. The objective of this study was to determine the effects of composted poultry litter (CPL) on subsoil physical and chemical properties. To simulate typical disturbance conditions, $20 \mathrm{~cm}$ of topsoil was removed and CPL was incorporated to a depth of $12.7 \mathrm{~cm}$ at $10 \%, 20 \%$, and $40 \% \mathrm{v} / \mathrm{v}$ prior to seeding or sodding. Composted plots were compared to fertilized $\left(454 \mathrm{Kg} \mathrm{ha}^{-1}\right)$ and control plots. Positive linear increases in total water content $\left(\theta_{T}\right)$, organic matter, $\mathrm{pH}$, and basic cations were observed following compost incorporation. Composted poultry litter increased the $\theta_{T}$ by $38 \%$ and decreased available water capacity $\left(A_{v}\right)$ and soil bulk density by $33 \%$ and $42 \%$, respectively. Compost applications increased organic matter by $6.4 \%$ in sodded plots and by $5.8 \%$ in seeded plots, along with an increase in $\mathrm{pH}$ from 6.0 to 7.4 . The soil cation exchange capacity (CEC) was increased by $186 \%$ in sodded plots and by $95 \%$ in seeded plots. No significant differences were observed between fertilized and control plots for all soil properties except for P levels, which increased. Overall, compost treatments were able to significantly improve soil physical and chemical properties compared to conventionally fertilized and control plots. 


\subsection{Introduction}

Since poultry litter contains almost all plant macro and micronutrients (Tyson and Cabrera, 1993), it is considered to be a valuable product and has been used as a soil amendment for many years. However, it can be a potential source of environmental contamination due to improper disposal and excessive use. Such a fate of PL can cause water pollution due to nitrate leaching into groundwater causing health problems such as methemoglobinaemia, cancer, and respiratory illness (Kelleher et al., 2002; Tyson and Cabrera, 1993). Other problems due to improper disposal of PL include enrichment of water bodies resulting in eutrophication, production of phytotoxic substances, air pollution, and emission of ozone depleting gases (Kelleher et al., 2002).

Poultry litter is traditionally used as a soil amendment to increase soil fertility and organic matter and to improve soil tilth (Gao and Chang, 1995; Eghball, 2002; Nyakatawa et al., 2001). Applications of PL to fields reduce synthetic fertilizer inputs and improve physical and chemical properties of soils. Accumulation and increased mobility of $\mathrm{P}$ in soils were found following application of non-composted poultry manure (Vadas et al., 2004). Thus, litter rates should be based on P requirements of the crop, and concentrations of $\mathrm{P}$ must be monitored if non-composted PL is to be used as a long-term fertilizer in agricultural production.

The environmental problems associated with the application of raw PL may be mitigated by composting. Composting poultry litter can provide a beneficial alternative method for handling litter due to nutrient immobilization. Composted litter is safer than raw litter because the process reduces pathogens, weeds seeds, and odor and the compost is easier to handle, store, transport, and apply compared to non-composted organic 
materials (Millner et al., 1998). The composting process converts the highly mobile nitrate in the litter to slow releasing nutrients and produces humus that can be used as a source of organic materials (Paul and Clark, 1996). The release of nutrients from CPL is slower than that from non-composted PL (Chang and Janzen, 1996). Composting also reduces total $\mathrm{P}$, due to dilution of manure with woodchips and straw, and water extractable $\mathrm{P}$ concentrations by immobilizing or stabilizing soluble forms of $\mathrm{P}$, compared with non-composted manures (Vadas et al., 2004).

The agronomic utilization of organic wastes is increasing along with the need to minimize disposal costs and to improve organic matter content of soils (Metzger and Yaron, 1987; Giusquiani et al., 1995). Land filling or incineration is the most widely accepted and inexpensive method for organic wastes disposal (National Research Council, 2002). Alternatively, these organic wastes can be composted and used as soil amendments providing an economical and environmentally safe alternative disposal method (Aggelides and Londra, 2000).

A considerable amount of research has been done to evaluate the effect of various organic materials on soil physical and chemical properties. Sewage sludge reduced bulk density, increased soil water content and available water, $\mathrm{CEC}$ and $\mathrm{pH}$ (Epstein et al., 1976; Tester, 1990). Municipal solid waste increased nutrient and water retention capacity, total pore space, and aggregate stability and decreased cone penetration resistance and bulk density (Avimelech et al., 1990; Shiralipour et al., 1992). Cattle feedlot manure increased soil organic carbon and water stable aggregates, and decreased bulk density and hydraulic conductivity of disturbed soils (Tiarks et al., 1974). Poultry litter has been shown to increase soil organic matter (Nyakatawa et al., 2001). Organic 
amendments have also been used in turfgrass culture to improve soil aeration capacity and water and nutrient retention while providing improved resiliency in an established turf (Turgeon, 1999). However, changes in soil properties responsible for improved fertility as a result of CPL applications to subsoil have not been addressed. The purpose of this study was to evaluate the changes in soil physical and chemical properties as a result of using CPL as a soil amendment to subsoil.

\subsection{Materials and Methods}

\subsubsection{Field Set-Up and Location}

Field experiments were established in fall 2003 at the West Virginia University, Agronomy Farm, near Morgantown. The soil was a Dormont silt loam (fine-loamy, superactive, mixed, mesic Oxyaquic Hapludalfs). Existing topsoil was removed to a depth of $20 \mathrm{~cm}$ and subsoil was exposed to simulate typical construction disturbance. The exposed subsoil was tilled and forty plots of $4.6 \mathrm{~m} \times 3.1 \mathrm{~m}$ separated by $0.6 \mathrm{~m}$ alleyways were delineated. The compost utilized for the experiments was derived from PL with wood chips and cardboard as a primary source of carbon with a ratio of 2:2:2 (N, $\mathrm{P}_{2} \mathrm{O}_{5}, \mathrm{~K}_{2} \mathrm{O}$ ) (Borderline LLC, Baker, WV). Other chemical characteristics of CPL are described in Table 3.1. Composted poultry litter was incorporated to a depth of $12.7 \mathrm{~cm}$ at three different rates. Treatments included control plots with no compost or fertilizer; fertilizer (20-27-5) applied at the rate of $454 \mathrm{Kg} \mathrm{ha}^{-1} ; 10 \%, 20 \%$, and $40 \%$ compost (v/v), equivalent to $43750 \mathrm{Kg} \mathrm{ha}^{-1}, 8.75^{*} 10^{4} \mathrm{Kg} \mathrm{ha}^{-1}$, and $1.75^{*} 10^{5} \mathrm{Kg} \mathrm{ha}^{-1}$, respectively. Plots were seeded on 7 October 2003 with Kentucky bluegrass seeds (Scotts 'Classic'; Kentucky bluegrass $97.75 \%, 0.05 \%$ other crop seeds, $2.11 \%$ inert matter, 0.09 weed seed) at the rate of $454 \mathrm{Kg} \mathrm{ha}^{-1}$ using a drop spreader. 
Seeded plots were then covered with straw mulch in order to retain moisture and help germination. The twenty remaining plots were sodded manually on 10 October 2003 with sod purchased from Rich Farm (Smithfield, PA). The turf was maintained at a height of $7.6 \mathrm{~cm}$ by mowing with a cordless electric reel mower. Plots were irrigated on an as needed. Rainfall data were collected during the months of May through September 2004.

\subsubsection{Compost Analysis}

The chemical characteristics of the compost used were determined in the Agronomy laboratory (Table 3.1). Total N, C, and S in CPL were determined using automated elemental analyzer. Levels of $\mathrm{Ca}$ and $\mathrm{Mg}$ as well as heavy metals $(\mathrm{Hg}, \mathrm{Mn}$, $\mathrm{Zn}, \mathrm{Cu}, \mathrm{Cr}, \mathrm{Ni}, \mathrm{Pd}, \mathrm{Cd}, \mathrm{Mo}, \mathrm{Al}$, and $\mathrm{Fe}$ ) were determined using inductively coupled plasma (ICP), whereas levels $\mathrm{Na}$ and $\mathrm{K}$ were determined using atomic absorption flame spectrophotometry. Two grams of compost was taken and digested with nitric and hydrofluoric acid, making a total volume of $50 \mathrm{ml}$ with boric acid.

\subsubsection{Soil Analysis}

Soil samples were collected twice during the study. Sub-samples were collected from various places from each plot and were mixed thoroughly to make one composite sample. Samples collected during February 2004 were air dried, machine ground and sieved through a 2-mm screen and were used to analyze CEC and levels of extractable $\mathrm{Ca}, \mathrm{P}, \mathrm{Mg}, \mathrm{Na}$, and K. Soil samples were collected again during January 2005 and were manually cleaned for any pebbles and debris and then air dried, hand ground, sieved through a 2-mm screen and were used to analyze available water and organic matter content. Basic properties of subsoil used in this study are summarized in Table 3.2. 
Table 3.1. Chemical characteristics of CPL used in this study

\begin{tabular}{cc}
\hline Characteristics & CPL \\
\hline $\mathrm{pH}$ & 8.3 \\
Total $\mathrm{K}^{\S}$ & 82.41 \\
Total $\mathrm{P}^{\ddagger}$ & 16.95 \\
Total $\mathrm{Ca}^{\ddagger}$ & 114.86 \\
Total $\mathrm{Na}^{\S}$ & 12.49 \\
Total $\mathrm{Mg}^{\ddagger}$ & 30.76 \\
Total $\mathrm{Hg}^{\ddagger}$ & 0 \\
Total $\mathrm{Mn}^{\ddagger}$ & 1.23 \\
Total $\mathrm{Zn}^{\ddagger}$ & 0.885 \\
Total $\mathrm{Cu}^{\ddagger}$ & 0.41 \\
Total $\mathrm{Cr}^{\ddagger}$ & 0.037 \\
Total $\mathrm{Ni}^{\ddagger}$ & 0 \\
Total $\mathrm{Pb}^{\ddagger}$ & 0.1 \\
Total $\mathrm{Cd}^{\ddagger}$ & 0.012 \\
Total $\mathrm{Mo}^{\ddagger}$ & 0 \\
Total $\mathrm{Al}$ & 36.85 \\
Total $\mathrm{Fe}^{\ddagger}$ & 32.3 \\
Total $\mathrm{S}(\%)^{\dagger}$ & 0.21 \\
Total $\mathrm{C}(\%)^{\dagger}$ & 24.51 \\
Total $\mathrm{N}(\%)^{\dagger}$ & 2.41 \\
$\mathrm{C} / \mathrm{N} \mathrm{ratio}^{\ddagger}$ & $10: 1$ \\
\hline
\end{tabular}

$\dagger$ Determined by Automated Elemental Analyzer

\$ Values in $\mathrm{mg} / \mathrm{g}$ as determined by Inductively Coupled Plasma (ICP) spectrophotometry after Nitric and Hydrofluoric acid digestion

$\S$ Values in $\mathrm{mg} / \mathrm{g}$ and determined by the Atomic Absorption Flame (AA)

spectrophotometry after Nitric and Hydrofluoric acid digestion 
Table 3.2 Properties of subsoil used in this study

\begin{tabular}{cc}
\hline Characteristics & Subsoil \\
\hline Texture & Silt loam \\
$\mathrm{pH}$ & 6.0 \\
$\mathrm{CEC}^{\dagger}$ & 10 \\
Available $^{\ddagger}$ & 73 \\
Extractable $^{\ddagger}$ & 113 \\
Extractable $^{\ddagger}$ & 2949 \\
${\text { Extractable } \mathrm{Mg}^{\ddagger}}^{\ddagger}$ & 241
\end{tabular}

$\dagger$ Value in $\mathrm{cmol}_{\mathrm{c}} \mathrm{Kg}^{-1}$ and determined by ammonium acetate-Kjeldahl method $\$$ Values in $\mathrm{Kg} \mathrm{ha}^{-1}$ and determined by Mehlich 1 extraction

The $\mathrm{pH}$ in water was measured with a glass electrode using 1:1 soil/water ratio (Thomas, 1996). Soil organic matter was determined by loss on ignition method (LOI) (Nelson and Sommers, 1996). The following equation derived from the Walkley Black method was used for correction based on soil types in Northeast and North Central states (Nelson and Sommers, 1996):

$$
\mathrm{O} . \mathrm{M}=[(0.8 * \mathrm{LOI} \%)-0.23]
$$

The CEC was determined by ammonium acetate-Kjeldahl method $\left(1.0 \mathrm{~N} \mathrm{NH}_{4} \mathrm{OAc}, \mathrm{pH}\right.$ (7)) (Sumner and Miller, 1996). Extractable $\mathrm{Ca}, \mathrm{P}$ and $\mathrm{Mg}$ were determined using inductively coupled plasma (ICP) and extractable $\mathrm{K}$ was determined by atomic absorption spectrophotometry (Perkin Elmer Model 100, Perkin Elmer Corp., Norwalk, CT) using Mehlich 1 extraction procedure. Soil texture was determined using the pipette method (Gee and Bauder, 1986).

Nondisturbed soil cores of known volume $\left(347.32 \mathrm{~cm}^{3}\right)$ were taken for bulk density using a hammer-driven core sampler. Bulk density was determined by measuring the dry weight (dried at $105^{\circ} \mathrm{C}$ ) and volume of soil in each core. Available water $\left(A_{v}\right)$ was determined using the pressure plate method (Klute, 1986). Soil samples were 
equilibrated with distilled water at 0.33 and 15 bars pressure. Available water was determined according to the following equation

$$
\mathrm{A}_{v}=\left[\left(W_{1 / 3}-W_{15}\right) *\left(\rho_{b}\right) *\left(\rho_{w}\right) *\left(C_{w}\right) \div 100\right]
$$

where $W_{1 / 3}$ and $W_{15}$ represent the weight percentage of water retained at $1 / 3$ bar and 15 bar, respectively, $\rho_{b}$ is the bulk density at $1 / 3$ bar water content on a $<2 \mathrm{~mm}$ basis $\left(\mathrm{g} / \mathrm{cm}^{3}\right)$, $\rho_{w}$ is the density of water $\left(\mathrm{g} / \mathrm{cm}^{3}\right)$, and $C_{w}$ represents a rock fragment conversion factor. In this study, $C_{w}$ was calculated using the following equation

$$
C_{w}=(100-(\text { volume }>2 \mathrm{~mm})) \div 100
$$

To determine total water content fresh soil samples of known volume $\left(347.32 \mathrm{~cm}^{3}\right)$ were taken from the field and their moist weight was recorded immediately. Samples were kept in an oven at $105^{\circ} \mathrm{C}$ for $48 \mathrm{~h}$ and the dry weight was recorded.

\subsubsection{Data Analysis}

Analysis of variance was used to analyze the data using PROC GLM ${ }^{\mathrm{TM}}$ (general linear models) procedure of the Statistical Analysis System (SAS Institute, 2002). The least significant difference (LSD) method, with a probability value of 0.05 , was used to determine significant differences between treatment means.

\subsection{Results and Discussion}

In this study, significant differences in water retention capacity, percent organic matter, bulk density, $\mathrm{pH}, \mathrm{CEC}$, and mineral nutrient content were observed among composted and fertilized and control plots (Table 3.3). Percent organic matter was not significantly affected by compost rates. 
Table 3.3. Analysis of variance for soil organic matter (OM), pH, CEC, bulk density, available water (AW), and mineral nutrient content

\begin{tabular}{|c|c|c|c|c|c|c|c|c|c|c|}
\hline Source of Variation & $\mathrm{n}$ & $\mathrm{OM}$ & $\mathrm{pH}$ & $\mathrm{CEC}^{\dagger}$ & Bulk density & AW & $\mathrm{P}$ & $\mathrm{K}$ & $\mathrm{Ca}$ & $\mathrm{Mg}^{\ddagger}$ \\
\hline & & & & & $\underline{\mathrm{P}>\mathrm{F}}$ & & & & & \\
\hline Control vs Others & 1 & $* *$ & $* * *$ & $* * *$ & $* *$ & $* * *$ & $* * *$ & $* * *$ & $* * *$ & $* * *$ \\
\hline Fertilizer vs Compost & 1 & $* *$ & $* * *$ & $* * *$ & $*$ & $* * *$ & $* * *$ & $* * *$ & $* * *$ & $* * *$ \\
\hline $\mathrm{C} 10$ vs $\mathrm{C} 20, \mathrm{C} 40$ & 1 & $*$ & $* * *$ & $* * *$ & $*$ & $* * *$ & NS & $* * *$ & $* * *$ & $* * *$ \\
\hline C20 vs C40 & 1 & NS & NS & $* *$ & NS & $* * *$ & NS & $* *$ & $*$ & $* *$ \\
\hline $\begin{array}{c}\text { Turf Type x Control vs } \\
\text { Others }\end{array}$ & 1 & - & NS & NS & NS & $\mathrm{NS}$ & $* *$ & NS & NS & NS \\
\hline $\begin{array}{c}\text { Turf Type x Fertilizer } \\
\text { vs Compost }\end{array}$ & 1 & - & NS & NS & NS & $* * *$ & NS & NS & $\mathrm{NS}$ & NS \\
\hline $\begin{array}{c}\text { Turf Type x C10 vs } \\
\text { C20, C40 }\end{array}$ & 1 & - & NS & NS & NS & $\mathrm{NS}$ & NS & NS & $\mathrm{NS}$ & NS \\
\hline $\begin{array}{l}\text { Turf Type x C20 vs } \\
\text { C40 }\end{array}$ & 1 & - & NS & $*$ & NS & NS & NS & NS & NS & NS \\
\hline
\end{tabular}

* Significant at $p<0.05$

** Significant at $p<0.01$

$* * *$ Significant at $p<0.001$

$\dagger$ Data are square root transformed

$\$$ Data are log transformed 


\subsubsection{Total Water Content and Soil Organic Matter}

The effect of percent compost on total water content, $\theta_{T}$, is presented in Fig 3.1. For both seeded and sodded treatments, percent soil water content was higher in compost treated plots than in fertilized plots and increased linearly with percent compost (sodded, $\mathrm{R}^{2}=0.95$; seeded, $\left.\mathrm{R}^{2}=0.73\right)$. This increase in $\theta_{T}$ is associated with an increase in the amount of organic matter (Fig. 3.2). In Fig 3.2, organic matter increased linearly (sodded $\mathrm{R}^{2}=0.94$; seeded $\mathrm{R}^{2}=0.98$ ) with increased compost rates. In fertilized and control plots, relatively high values of organic matter $(2.8 \%)$ were recorded. The reason for this is not readily apparent.

The increases in $\theta_{T}$ results from both the increase in organic matter and its effect on soil physical properties. The application of organic matter to soil is usually followed by reduced evaporation, by acting as mulch (Havlin et al., 1999), and increase in the total amount of soil water due to the ability of organic matter to absorb large amounts of water (up to 20 times its weight) (Stevenson, 1982.). This ability is related to the large number of hydrophilic aromatic and aliphatic compounds in the organic matter structure (Evangelou, 1998). The effects of organic matter on soil physical properties include improved aggregation, by acting as cementing agents between various soil particles, and increased porosity (Stevenson, 1982). This process of aggregation improves water infiltration, soil tilth and subsequently plant growth especially in loamy soils (average \% clay $=24 \%$ in subsoil used in this study). 


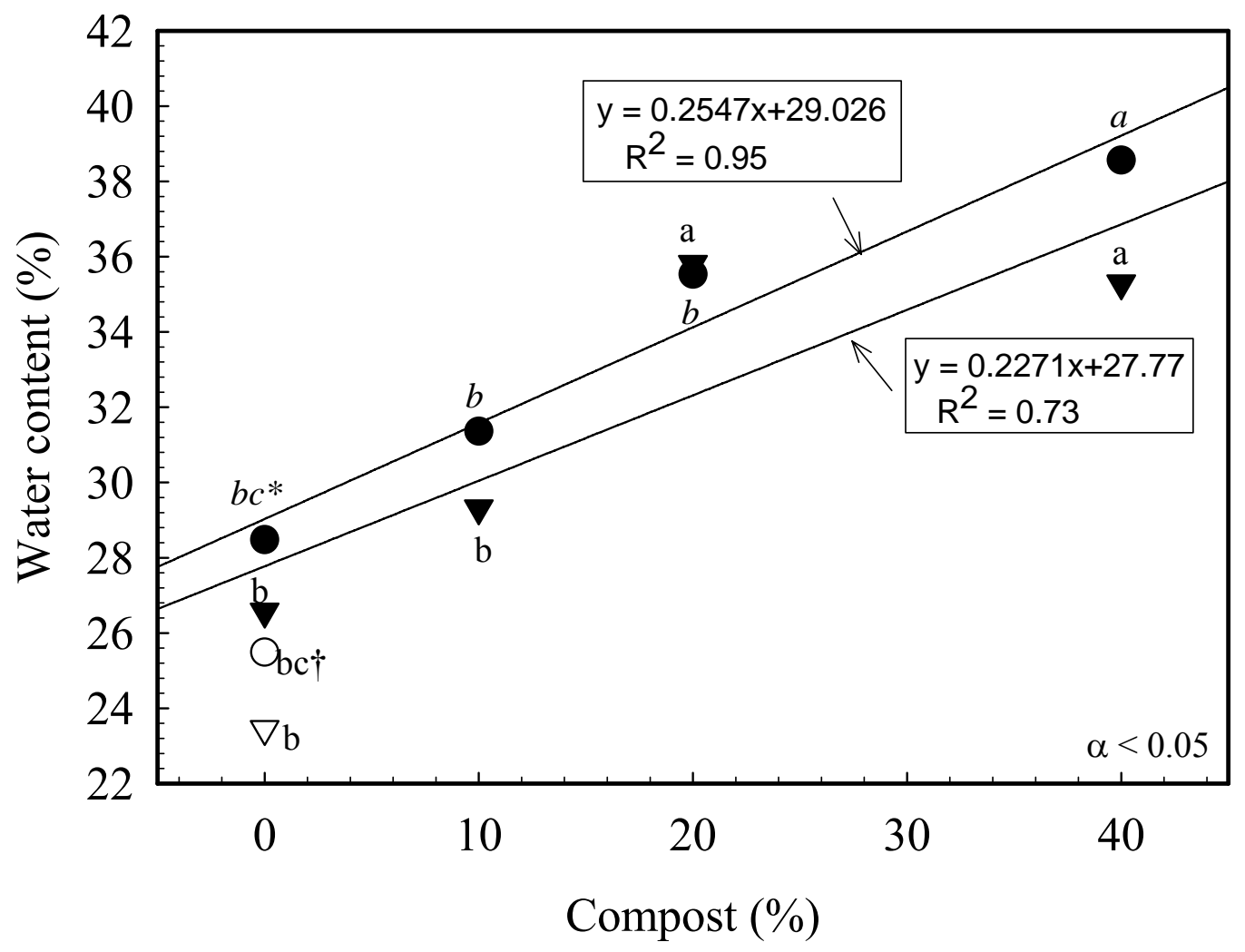

Fig. 3.1 Effect of incorporating composted poultry litter into top $16 \mathrm{~cm}$ of subsoil on total percent water content $\left(\theta_{T}\right)$ by volume for $\bullet$ sodded compost; o sodded fertilizer; $\nabla$ seeded compost; and $\nabla$ seeded fertilizer plots.

* Means with same letters are statistically insignificant at $p<0.05$

$\dagger$ values for standard error were small ranging between 0.085 (min.) to 0.553 (max.) and hence are not shown in figure. 


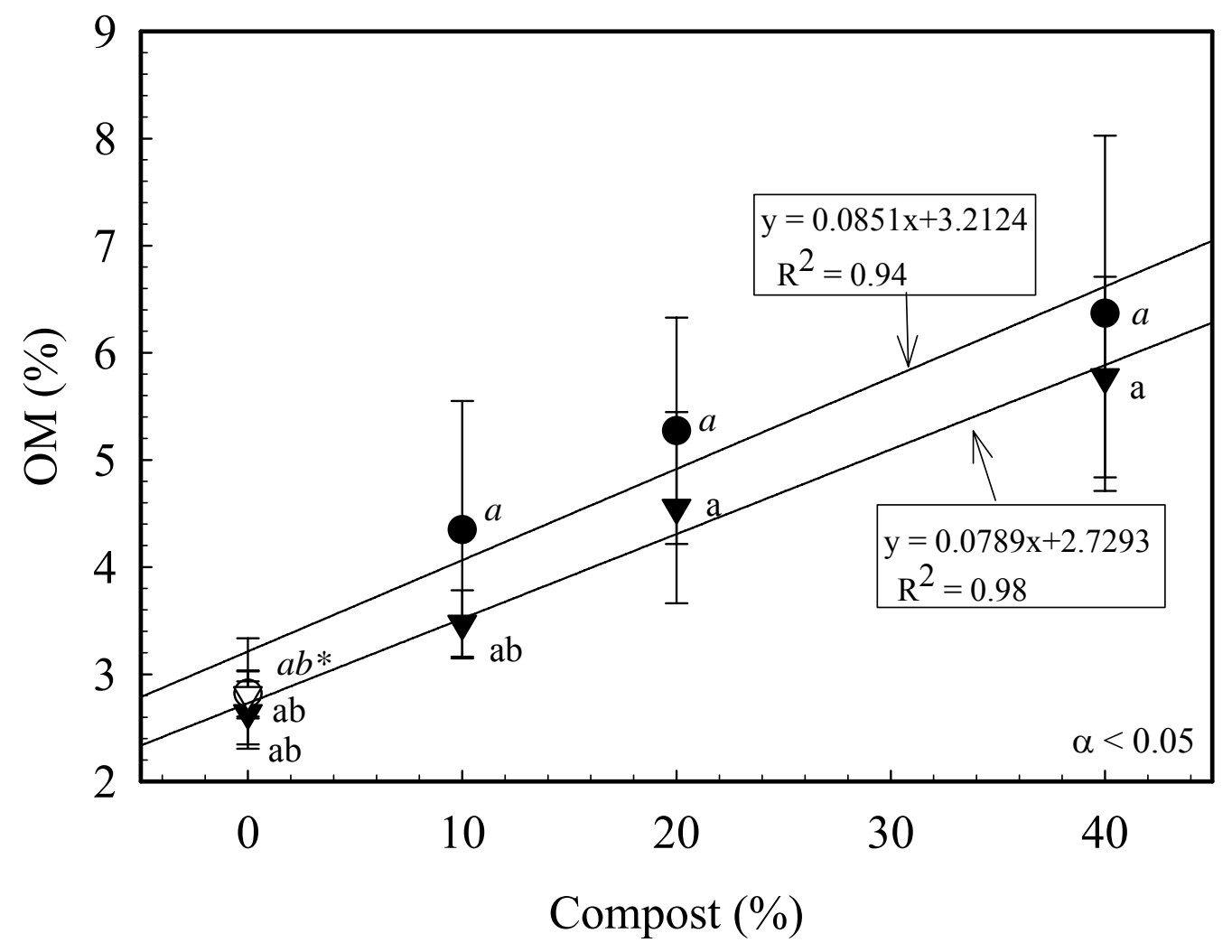

Fig. 3.2 Effect of incorporating composted poultry litter into top $16 \mathrm{~cm}$ of subsoil on organic matter for $\bullet$ sodded compost; o sodded fertilizer; $\boldsymbol{\nabla}$ seeded compost; and seeded fertilizer plots.

* Means with same letters are statistically insignificant at $p<0.05$ 


\subsubsection{Available Water Capacity and Soil Bulk Density}

Figure 3.3 shows a linear and negative relationship between percent compost and available water, $A_{v}$ (sodded, $\mathrm{R}^{2}=0.89$; seeded, $\mathrm{R}^{2}=0.97$; slope $=-0.002$ ). As percent compost increased, $A_{v}$ decreased (Fig 3.3) whereas the total amount of water in soil (Fig 3.1) increased. This suggests that the higher the compost rate, the larger is the total volume of water held by soils and lower is the volume available for plant uptake (more water is retained by soil particles). Amount of water held by soil at $1 / 3$ and 15 bar are shown in Table 3.4.

In this study, we determined both $\theta_{T}$, and $\mathrm{A}_{v}$, since each measured a different pool of water. Soil water content measures the total amount of water held by soil ( $\theta_{T}=\mathrm{A}_{v}+$ Unvailable) whereas $\mathrm{A}_{v}$ determines the amount of water that can be extracted by plants. This water is held between field capacity and wilting point by capillary forces (Hillel, 2004).

Organic matter addition has been reported to increase $A_{v}$ only in coarse textured soils with $<15 \%$ clay. With soils having $>15 \%$ clay such as the soil used in this study ( $24 \%$ clay), factors others than organic matter determine $A_{v}$ (Jamison, 1953). 


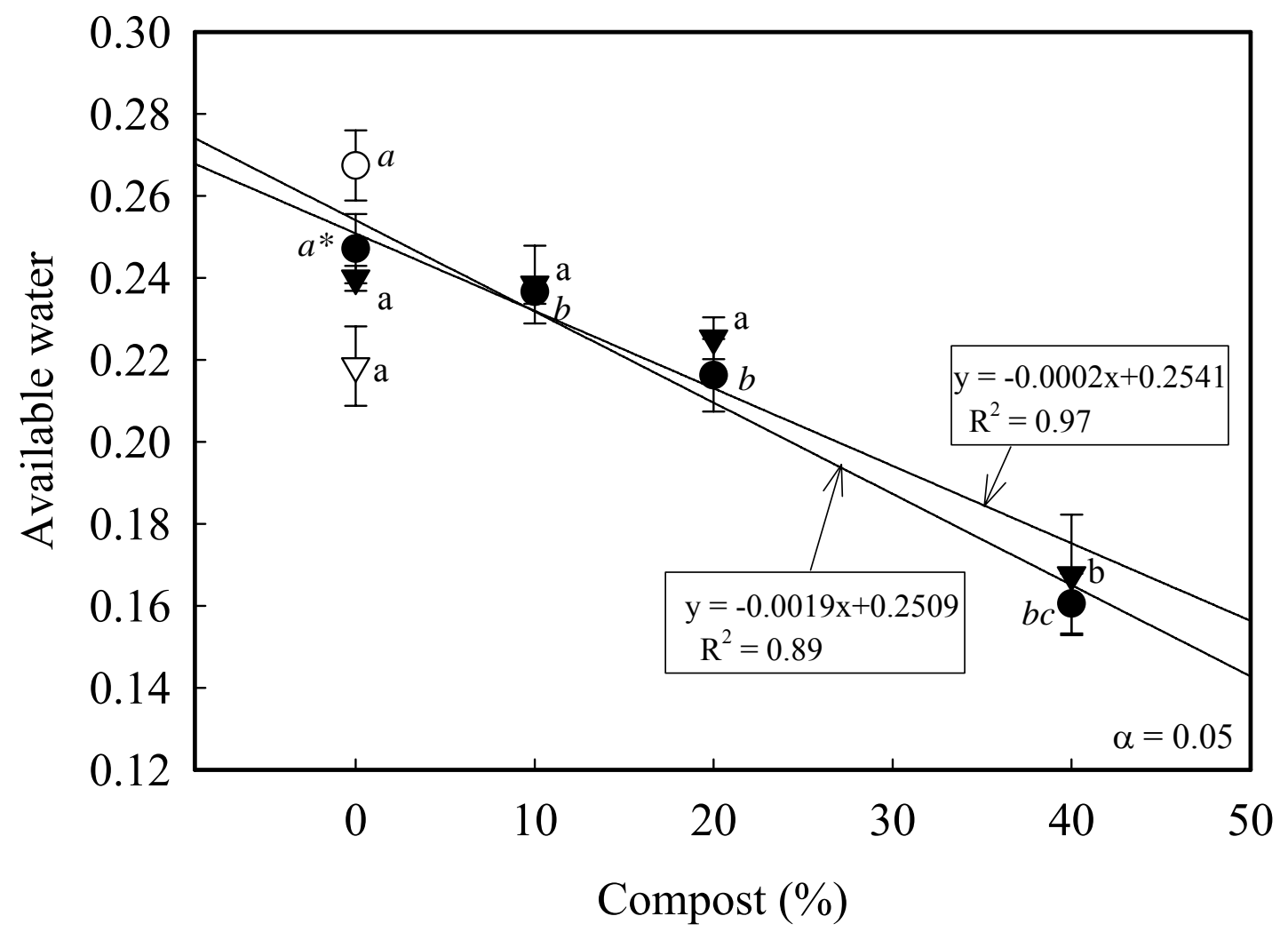

Fig. 3.3 Effect of incorporating composted poultry litter into top $16 \mathrm{~cm}$ of subsoil on available water, $A_{v}$ for $\bullet$ sodded compost; o sodded fertilizer; $\boldsymbol{\nabla}$ seeded compost; and seeded fertilizer plots.

* Means with same letters are statistically insignificant at $p<0.05$ 
Table 3.4. Effect of different treatments on percent (by weight) of water held by subsoil

\begin{tabular}{ccc}
\hline Treatments & $1 / 3$ bar & 15 bar \\
\hline & Seeded & \\
$40 \%$ Compost & 33.5 & 15.2 \\
$20 \%$ Compost & 32.5 & 14.2 \\
10\% Compost & 31.5 & 13.9 \\
Fertilizer & 32.2 & 14.0 \\
Control & 30.0 & 13.1 \\
& Sodded & \\
40\% Compost & 35.7 & 15.9 \\
20\% Compost & 33.4 & 14.8 \\
$10 \%$ Compost & 34.2 & 14.8 \\
Fertilizer & 28.0 & 11.2 \\
Control & 28.8 & 11.8 \\
\hline
\end{tabular}

Authors have reported different effects of compost on $A_{v}$. These effects which varied from increase, decrease and no change of $A_{v}$ with compost additions were generally related to variation in the soil physical properties such as texture, (Stevenson, 1974; Metzger and Yaron, 1986), pore size distribution (Stevenson, 1974), percent clay and structure (Jamison, 1953), and bulk density (Stevenson, 1974; Reeve et al., 1973).

Angle et al. (1981) reported an increase in $\theta_{T}$ of soil with increased rate of sludge compost but observed no effect on $A_{v}$. Jamison and Kroth (1958) attributed the changes in $A_{v}$ to the increase in either percent silt or clay and their effect on pore size distribution. They concluded that the clay particles in silt loam soils with more than $20 \%$ clay reduced the water storage by diluting the soil mass and shifting the pore size distribution towards smaller pores, where more water is held in an unavailable range. Metzger and Yaron (1986) observed an increase in $A_{v}$ of sandy soils, whereas that of a loamy soil remained unchanged upon addition of sludge. MacRae and Mehuys (1985) reported a decrease in 
$A_{v}$ in silt loam following the addition of peat at different rates $(10 \%, 20 \%, 30 \%$, and $50 \%$ $\mathrm{v} / \mathrm{v})$.

Stevenson (1974) explained that the net result of organic material addition on $A_{v}$ depends on the relative changes in percent water by weight of soil $\left(W_{15}-W_{1 / 3}\right)$ and decreases of bulk densities dictated by soil type. For silt loam, Stevenson (1974) associated the decrease in $A_{v}$ (at 0.3 bars) to a consistent decrease in soil bulk density with peat moss addition. These observations agree with my results (Fig. 3.4). For silt loam soils, the decrease in $A_{v}$ (Fig 3.3) is associated with a decrease in bulk density (as shown in Fig. 3.4). Soil bulk density decreased linearly (up to $42 \%$ with $40 \%$ compost) with increasing rates of compost (sodded, $\mathrm{R}^{2}=0.98$; seeded, $\mathrm{R}^{2}=0.97$ ). Decrease in bulk density is generally associated with the low particle density of organic matter, which when mixed with the mineral fractions of soils greatly improves aggregation and porosity (MacRae and Mehuys, 1985). The reduction in the soil bulk density with organic material addition is also related to factors such as compost application rate, soil type, and extent of soil compaction (McConnell et al., 1993). Wei et al. (1985) also observed a $6.3 \%$ decrease in bulk density of silty clay loam by the application of sludge compost at $13.44 * 10^{-5} \mathrm{Kg} \mathrm{ha}^{-1}$. 


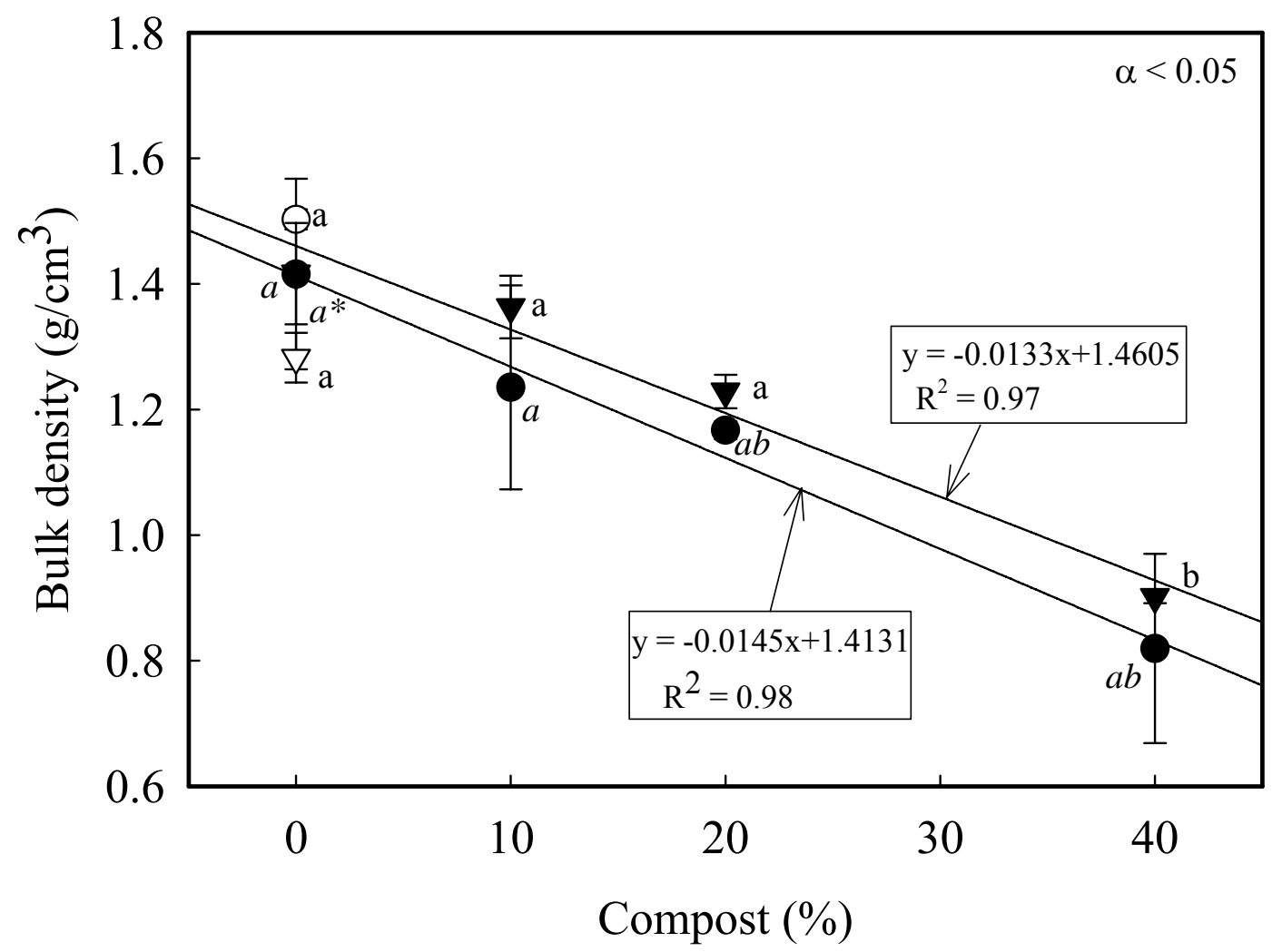

Fig. 3.4 Effect of incorporating composted poultry litter into top $16 \mathrm{~cm}$ of subsoil on soil bulk density for $\bullet$ sodded compost; o sodded fertilizer; $\boldsymbol{\nabla}$ seeded compost; and seeded fertilizer plots.

* Means with same letters are statistically insignificant at $p<0.05$

\subsubsection{Soil Chemical Properties}

The addition of compost to subsoil increased $\mathrm{pH}$ linearly (sodded, $\mathrm{R}^{2}=0.97$, seeded, $\left.\mathrm{R}^{2}=0.84\right)$ from 6.2 (control) to $7.4(40 \%$ compost) (Fig. 3.5$)$ and resulted in an increase in soil basic cations (Table 3.5). These effects are explained by the initial $\mathrm{pH}$ of CPL (8.3) and its high basic cation content (Table 3.5). Increases in soil pH through compost application (PL) have also been reported by Rasnake and Murdock (2002) and 
Gagnon (2004). They attributed this increase to the high Ca content of PL and its effect on exchangeable soil $\mathrm{Ca}$.



Fig. 3.5 Effect of incorporating composted poultry litter into top $16 \mathrm{~cm}$ of subsoil on soil $\mathrm{pH}$ for $\bullet$ sodded compost; o sodded fertilizer; $\nabla$ seeded compost; and $\nabla$ seeded fertilizer plots.

* Means with same letters are statistically insignificant at $p<0.05$ 
Table 3.5 Effect of incorporating composted poultry litter into top $16 \mathrm{~cm}$ of subsoil on soil mineral nutrient content of seeded and sodded plots

\begin{tabular}{ccccc}
\hline Treatments & $\mathrm{P}$ & $\mathrm{K}$ & $\mathrm{Ca}$ & $\mathrm{Mg}$ \\
\hline & \multicolumn{3}{c}{ Seeded } \\
$40 \%$ compost & $241^{\mathrm{a}^{*}}$ & $2337^{\mathrm{a}}$ & $9087^{\mathrm{a}}$ & $1671^{\mathrm{a}}$ \\
$20 \%$ compost & $232^{\mathrm{a}}$ & $1915^{\mathrm{a}}$ & $7606^{\mathrm{b}}$ & $919^{\mathrm{b}}$ \\
$10 \%$ compost & $227^{\mathrm{a}}$ & $1306^{\mathrm{ab}}$ & $4879^{\mathrm{bc}}$ & $620^{\mathrm{b}}$ \\
Fertilizer & $110^{\mathrm{b}}$ & $128^{\mathrm{b}}$ & $2661^{\mathrm{bcd}}$ & $255^{\mathrm{bc}}$ \\
Control & $101^{\mathrm{b}}$ & $245^{\mathrm{b}}$ & $2708^{\mathrm{bcd}}$ & $288^{\mathrm{bc}}$ \\
$40 \%$ compost & $240^{\mathrm{a}}$ & $\underline{20 d d e d}$ & & \\
$20 \%$ compost & $237^{\mathrm{a}}$ & $1236^{\mathrm{b}}$ & $7929^{\mathrm{a}}$ & $1530^{\mathrm{a}}$ \\
$10 \%$ compost & $227^{\mathrm{a}}$ & $738^{\mathrm{b}}$ & $4442^{\mathrm{b}}$ & $946^{\mathrm{b}}$ \\
Fertilizer & $91^{\mathrm{b}}$ & $158^{\mathrm{bc}}$ & $2156^{\mathrm{bc}}$ & $264^{\mathrm{bcd}}$ \\
Control & $55^{\mathrm{bc}}$ & $259^{\mathrm{bc}}$ & $2266^{\mathrm{bc}}$ & $250^{\mathrm{bcd}}$ \\
\hline
\end{tabular}

* Different letters in the same column indicate a significant difference at $p<0.05$ 
Control plots had $\mathrm{pH}$ of 6.2 while fertilized plots had a $\mathrm{pH}$ of 5.9 (Fig. 3.5). This decrease in $\mathrm{pH}$ is expected and results from the application of fertilizer with composition of $\mathrm{NH}_{4}-\mathrm{N}(4.7 \%)$, urea (8.3\%), other water soluble $\mathrm{N}(6.4 \%)$, and water insoluble $\mathrm{N}$ (0.6\%). $\mathrm{NH}_{4}-\mathrm{N}$ fertilizers are known to decrease $\mathrm{pH}$ through leaching of basic cations and production of $\mathrm{H}^{+}$as a result of nitrification (Havlin et al., 1999). In this study, leaching of basic cations is most likely responsible for the lower $\mathrm{pH}$ in fertilized plots, which results from exchange of cations with $\mathrm{NH}_{4}{ }^{+}$ions. Our results are consistent with those of Rasnake and Murdock (2002) and Eghball (2002) who reported a decrease in pH from 6.7 to 6.3 and 6.4 to 5.6 respectively, following $\mathrm{NH}_{4}-\mathrm{N}$ fertilizer applications.

Soil CEC increased from $11 \mathrm{cmol}_{\mathrm{c}} \mathrm{kg}^{-1}$ (control) to an average of $28 \mathrm{cmol}_{\mathrm{c}} \mathrm{kg}^{-1}$ with increasing rates of compost application (Fig. 3.6). This increase in CEC can be explained by both the increase in the amount of organic matter added with the higher rates of compost $\left(\mathrm{CEC}\right.$ of organic matter $=100-300 \mathrm{cmol}_{\mathrm{c}} \mathrm{kg}^{-1}$, Evangelou, 1998) and the increases in $\mathrm{pH}$ with $\mathrm{CPL}$ addition (Fig. 3.5). The effect of $\mathrm{pH}$ on CEC is most prominent in soils with a significant amount of $\mathrm{pH}$-dependent clays (Evangelou, 1998). In this study, the mineralogical composition of our soils was not determined, but based on the low CEC of our control plots $\left(11 \mathrm{cmol}_{\mathrm{c}} \mathrm{kg}^{-1}\right) \mathrm{I}$ believe that it is mostly formed of $\mathrm{pH}$ dependent clays. Gao and Chang (1996) also observed increases in CEC following cattle feedlot manure applications and attributed this increase mainly to the increase in organic matter.

In general, the addition of compost to subsoil improved its nutrient content (Table 3.5). Higher concentrations of $\mathrm{P}, \mathrm{K}, \mathrm{Mg}$ and $\mathrm{Ca}$ were observed at $40 \%$ compost rate for both seeded and sodded plots. This increase in nutrient content reflects the rich nutrient 
composition of CPL (Table 3.1). Levels of basic cations ( $\mathrm{Ca}, \mathrm{K}, \mathrm{Mg}$, and $\mathrm{Na}$ ) increased linearly and consequently increased base saturation.

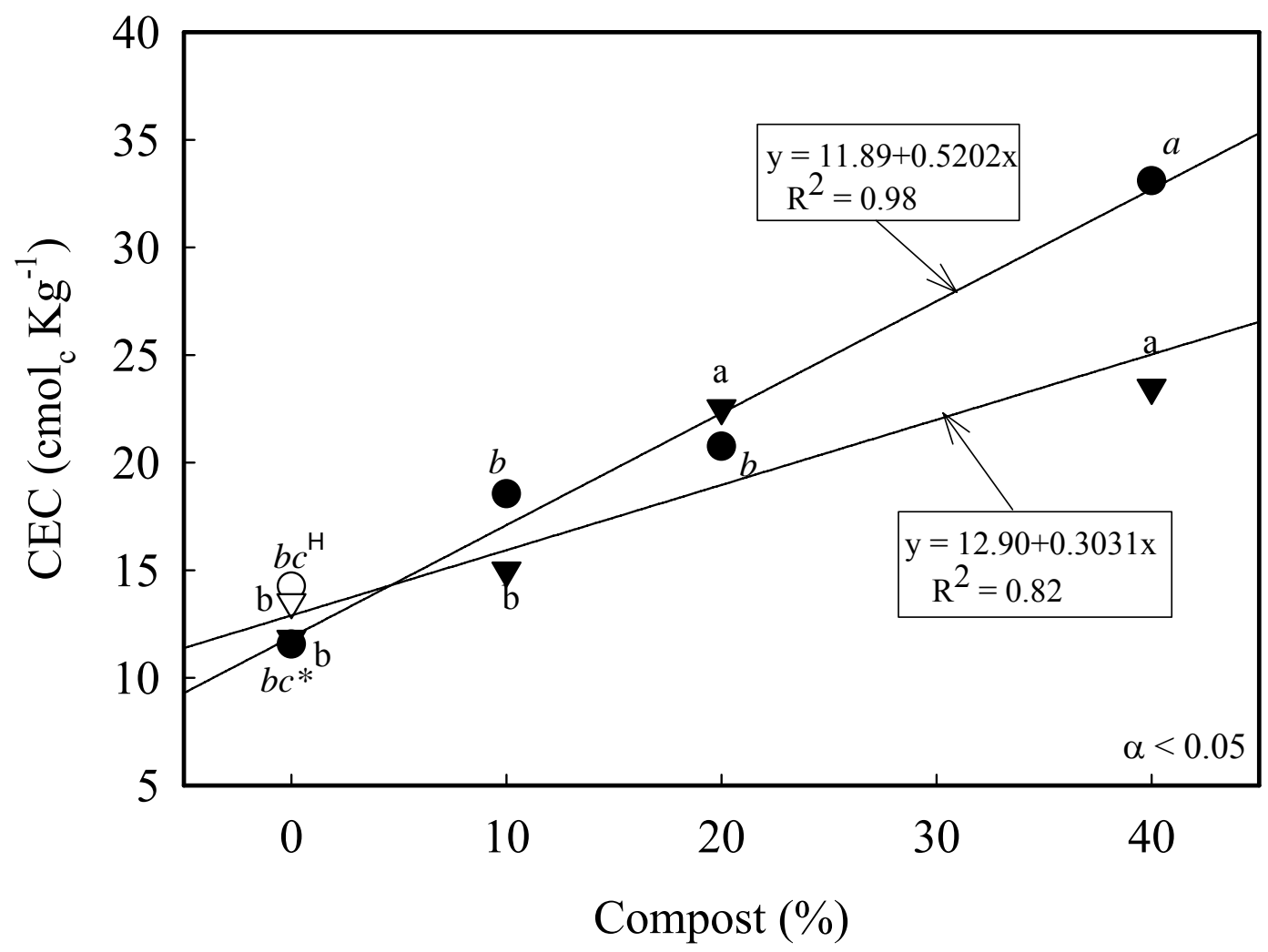

Fig. 3.6 Effect of incorporating composted poultry litter into top $16 \mathrm{~cm}$ of subsoil on cation exchange capacity (CEC) for $\bullet$ sodded compost; o sodded fertilizer; $\boldsymbol{\nabla}$ seeded compost; and $\nabla$ seeded fertilizer plots

* Means with same letters are statistically insignificant at $p<0.05$

$\uparrow$ values for standard error were small ranging between 0.065 (min.) to 0.443 (max.) and hence are not shown in figure.

Potassium levels increased from $0.68 \mathrm{cmol}_{\mathrm{c}} \mathrm{kg}^{-1}$ (control) to $7.3 \mathrm{cmol}_{\mathrm{c}} \mathrm{kg}^{-1}(40 \%$ compost), whereas, $\mathrm{Ca}^{2+}$ increased from $7 \mathrm{cmol}_{\mathrm{c}} \mathrm{kg}^{-1}$ (control) to $16 \mathrm{cmol}_{\mathrm{c}} \mathrm{kg}^{-1}$. Gagnon and Simard (1999) reported 11\% increase in available soil $\mathrm{P}$ in plots treated with industrial compost and 38\% increase in PL compost-treated plots. This increase in P was 
linearly related to the amount of total $\mathrm{P}$ in compost. Significantly larger increases in soil P (from 52\% and 240\%) were reported by Balkcom et al., (2003).

\subsection{Seeded versus Sodded Turf}

Increases in organic matter and $\theta_{T}$ were higher in sodded plots as compared to seeded plots in all treatments (Figs. 3.1 and 3.2). In sodded plots, organic matter increased from $2.8 \%$ (control) to $6.4 \%$ (40\% compost). Total water content in sodded plots increased from $29 \%$ in control plots up to $39 \%$ with $40 \%$ compost treatments. In seeded plots, $\theta_{T}$ increased from $27 \%$ in control plots up to $35 \%$ with $40 \%$ compost (Fig. 3.1). Higher increases in organic matter in sodded plots compared to seeded plots are attributed to the well-established root system of sodded turfgrass as compared to newly seeded turf. The higher $\theta_{T}$ in sodded plots is explained by the well-established cover and root system of turf. The dense turf cover increases water content by reducing evaporation whereas the root system holds up more water.

Soil $\mathrm{pH}$ increased more in seeded than sodded plots. In sodded plots, the denser root system is believed to contribute more to acidity through the excretion of organic acids. At 40\% compost rate, sodded plots showed a significantly higher CEC than seeded

plots $\left(34 \mathrm{cmol}_{\mathrm{c}} \mathrm{kg}^{-1}\right.$ in sodded as compared to $23 \mathrm{cmol}_{\mathrm{c}} \mathrm{kg}^{-1}$ in seeded) (Fig. 3.6). This significant difference in CEC cannot be explained and might be the result of an experimental artifact in the soil sample preparation (grinding of roots).

\subsection{Conclusions}

In this study, CPL improved the physical and chemical properties of the silt loam subsoil. Positive linear increases in $\theta_{T}$, organic matter, $\mathrm{pH}, \mathrm{CEC}$, and mineral nutrient content were observed with a linear decrease in soil bulk density and $A_{v}$ by CPL 
incorporation. Improvement in soil physical and chemical properties of subsoil is attributed to the direct supply of organic matter and essential nutrients by CPL. Both the amount and composition of organic matter added to the soil affect the extent to which its physical and chemical properties are modified. These results demonstrate that CPL can be used to enhance the soil physical and chemical properties of eroded or disturbed soils. Amending soils with organic wastes can have two advantages; apart from managing the disposal problem it can also improve nutrient and organic matter content. 


\title{
4. Amending Subsoil with Composted Poultry Litter-II: Effects on Turfgrass Establishment, Root Growth and Weed Pressure
}

\begin{abstract}
4.1 Abstract
Experiments were established in fall 2003 at West Virginia University to evaluate the effects of incorporation of composted poultry litter (CPL) on Kentucky bluegrass (Poa Pratensis L.) establishment, root depth, and weed pressure. To simulate construction disturbance, $20 \mathrm{~cm}$ of topsoil was removed. Composted poultry litter was incorporated to a depth of $12.7 \mathrm{~cm}$ at $10 \%, 20 \%$, and $40 \% \mathrm{v} / \mathrm{v}$ prior to seeding or sodding. Composted plots were compared to N-fertilized $\left(454 \mathrm{Kg} \mathrm{ha}^{-1}\right)$ and control plots. Turf was maintained at a mowing height of $7.6 \mathrm{~cm}$. The incorporation of CPL enhanced turfgrass establishment, growth, and root depth significantly $(p<0.05)$. Positive linear relationships were observed between Kentucky bluegrass yield and compost rates. Clippings dry weight from seeded plots with $10 \%, 20 \%$, and $40 \%$ compost showed approximately $200 \%, 300 \%$, and $500 \%$ more dry weight, respectively, compared to seeded control. Similarly, sodded plots with $10 \%, 20 \%$, and $40 \%$ compost yielded $2,2.5$, and 3.5 times more dry weight, respectively, than the sodded control. Kentucky bluegrass root depth also increased linearly with compost rates. In spring $2004,85 \%$ turfgrass cover was recorded in plots with $20 \%$ compost followed by $64 \%$ and $76 \%$ in plots with $10 \%$ and $40 \%$ compost, respectively. One year after seeding, all composttreated plots exhibited $100 \%$ turf cover. Plots with $20 \%$ and $40 \%$ compost had $6 \%$ and $72 \%$ fewer total weeds, respectively, than the control, whereas, $10 \%$ compost treated plots had $37 \%$ more weeds than control plots. Fertilized plots showed about $20 \%$ less turfgrass growth than seeded and sodded control plots and exhibited weed pressure
\end{abstract}


similar to the control. Overall, compost treatments were able to maintain superior turf cover and quality and lower weed populations compared to conventionally fertilized or control plots.

\subsection{Introduction}

Establishing turfgrass in a suitable medium is paramount to its vigor and ability to tolerate pests. During construction disturbance, topsoil is often either lost or mixed with subsoil which is often high in clay and low in organic matter and nutrients (Landschoot and McNitt, 1994b). Turfgrasses established on such disturbed soils are weak and more prone to pests and diseases. Furthermore heavy equipment may compact the soil and make conditions unfavorable for turfgrass establishment and growth in these disturbed soils (Loschinkohl and Boehm, 2001). Amending these disturbed soils with organic wastes (compost) can improve the fertility and physical and chemical properties of soil, and provide a more suitable seed-bed for turfgrass.

Turfgrass establishment was significantly enhanced by the incorporation of composted biosolids into disturbed soil (Loschinkohl and Boehm, 2001). Larney and Janzen (1996) reported that livestock manures (hog manure and poultry manure) could restore productivity to eroded soils by substituting for lost topsoil. An increasing urban waste stream and restrictions on the methods of waste disposal have fueled resurgence in the use of composted organic wastes, which have the potential to serve as useful resources in turfgrass management (Schumann et al., 1993). Various kinds of organic wastes like biosolids, municipal sewage, PL, SS, and YT have been used as amendments for turf areas. 
Beneficial effects of compost as an amendment and topdressing have been observed on turfgrasses. Compost helps turf to establish faster with improved density, color (Gentilucci et al., 2001; Strange et al., 1998) and with increased rooting systems (Landschoot and McNitt, 1994a). Various compost and organic materials help in rapid healing of cored turf, dollar spot suppression, and thatch reduction (Dinelli, 1999). Composts have been shown to be an effective and safe nutrient source and to increase yield of tall fescue (Kiemnec et al., 1987; Rasnake and Murdock, 2002; Tester, 1989). Angle et al. (1981) have shown that compost can improve the rate of turfgrass establishment from seed and sod and its general appearance. Municipal solid waste has been shown to increase the root mass of St. Augustinegrass (Chandran, 1993). Composted poultry litter decreases the susceptibility of Kentucky bluegrass to drechslera leaf spot disease (Chandran et al., 2005). Land application of PL is a feasible, practical, economically and environmentally sound method of disposal (Lucero et al., 1995).

Municipal solid waste and biosolids compost applied to soils may suppress weeds due to phytotoxic compounds and high $\mathrm{CO}_{2}$ levels resulting from biological activity and high temperatures in composts can decrease germination of weeds below the soil surface (Ozores-Hampton et al., 1999; Shiralipour and McConell, 1991). The process of composting generates heat to levels sufficient to kill inherent weed seeds like ivyleaf morning glory [Ipomoea hederacea L.], barnyardgrass [Echinochloa crus-galli L.], and common purslane [Potulaca oleracea L.] (Ozores-Hampton et al., 1999). In a study conducted by Mandal and Chandran (2005), CPL has been shown to decrease or inhibit the germination of weeds such as common lambsquarters [Chenopodium album L.], giant foxtail [Setaria faberi Herrm.], green foxtail [Setaria viridis (L.) Beauv.], ivyleaf 
morningglory, johnsongrass [Sorghum halepense (L.) Pers.], large crabgrass [Digitaria sanguinalis (L.) Scop.], pigweed [Amaranthus hybridus L.], ragweed [Ambrosia artemisiifolia L.], small flower morning glory [Jacquemontia tamnifolia (L.) Griseb.], and yellow foxtail [Setaria glauca (L.) Beauv.].

Pesticides are often used to control pests such as insects and weeds. Of all the environmental contaminants, pesticides have been most widely criticized due to their negative impact on the environment (Connell, 1997). Negative effects associated with the use of pesticides on the environment and human health has been well documented (Ross and Lembi, 1999). Ability of compost to suppress weed germination and to suppress diseases can reduce the use of pesticides and can provide a sustainable system for pest management.

Although different kinds of composts have been used as amendments to study effects on turfgrass growth and establishment, limited information is available on the usefulness of CPL to amend subsoil for turfgrass growth, establishment, and weed control. The turfgrass industry can have two potential advantages of using CPL as a soil amendment. Apart from managing disposal of this waste product, it can also help in the growth and establishment of turfgrass. However, to become a widely used as a soil amendment CPL must maintain yield and quality of turfgrasses. The objectives of this research were to evaluate the (a) effects of CPL incorporation into subsoil on the establishment and subsequent growth attributes of Kentucky bluegrass and its effect on weed population and (b) effects of CPL on turfgrass root growth. 


\subsection{Materials and Methods}

\subsubsection{Field Experimentation and Location}

Field experiments were established in fall 2003 at the West Virginia University, Agronomy Farm, near Morgantown. The soil was a Dormont silt loam (fine-loamy, superactive, mixed, mesic Oxyaquic Hapludalfs). Existing topsoil was removed to a depth of $20 \mathrm{~cm}$ and subsoil was exposed to simulate typical construction disturbance. The exposed subsoil was tilled and forty plots of $4.6 \mathrm{~m} \mathrm{x} 3.1 \mathrm{~m}$ separated by $0.6 \mathrm{~m}$ alleyways were delineated. The compost utilized for the experiments was derived from PL with wood chips and cardboard as a primary source of carbon with a ratio of 2:2:2 (N, $\mathrm{P}_{2} \mathrm{O}_{5}, \mathrm{~K}_{2} \mathrm{O}$ ) (Borderline LLC, Baker, WV). Composted poultry litter was incorporated to a depth of $12.7 \mathrm{~cm}$ at three different rates. Treatments included control plots with no compost; fertilizer (20-27-5) applied at the rate of $454 \mathrm{Kg} \mathrm{ha}^{-1} ; 10 \%, 20 \%$, and $40 \%$ compost (v/v), equivalent to $43750 \mathrm{Kg} \mathrm{ha}^{-1}, 8.75^{*} 10^{4} \mathrm{Kg} \mathrm{ha}^{-1}$, and $1.75^{*} 10^{5} \mathrm{Kg} \mathrm{ha}^{-1}$, respectively. Plots were seeded with Kentucky bluegrass on October 7, 2003 (Scotts 'Classic'; Kentucky bluegrass 97.75\%, 0.05\% other crop seeds, 2.11\% inert matter, 0.09 weed seed) at the rate of $454 \mathrm{Kg} \mathrm{ha}^{-1}$ with the help of a drop spreader. Seeded plots were then covered with straw mulch in order to retain moisture and help in germination. Twenty remaining plots were sodded manually on October 10, 2003. Sod was bought from Rich Farm (Smithfield, PA). The turf was maintained at a mowing height of $7.6 \mathrm{~cm}$ with the help of a cordless electric reel mower. Clippings were collected every time the grass height reached more than $7.6 \mathrm{~cm}$, except for the first time when grass was allowed to grow up to $20 \mathrm{~cm}$ to prevent young seedlings from getting damaged. The fresh and dry clipping weights were recorded. The 2004 growing season was cool and wet. A total of 
$68.12 \mathrm{~cm}$ of precipitation was recorded from May to September 2004 (Table 4.1) that was adequate to keep the site wet. No supplemental irrigation was therefore provided to the plots during May to September 2004.

Table 4.1 Precipitation recorded from May to September in 2004

\begin{tabular}{cc}
\hline Month & $\begin{array}{c}\text { Rainfall in 2004 } \\
(\mathrm{cm})\end{array}$ \\
\hline May & 13.36 \\
June & 12.45 \\
July & 9.02 \\
August & 16.23 \\
September & 17.07 \\
Total & 68.12 \\
\hline
\end{tabular}

\subsubsection{Evaluation of Turfgrass Establishment and Growth}

Turfgrass establishment was assessed by quantifying percent turfgrass cover and seedling count. Bare area percentage was measured twice during the growing season (April and September 2004) by tieing two strings diagonally in each plot and measuring the bare area along the strings. Any bare spot greater than $5 \mathrm{~cm}$ in diameter was included in the measurement. Percent turfgrass cover was determined by percent bare area in seeded plots (in sodded plots ground cover remained 100\% regardless of different treatments). Seedlings were counted within $7.6 \mathrm{~cm} \times 7.6 \mathrm{~cm}$ grid area placed randomly at eight different locations in each plot.

Turfgrass growth was measured from dry clipping weights and seedling heights from each plot. Clippings were collected from the center of each plot (lengthwise and widthwise) in an area of $3.2 \mathrm{~m}^{2}$. The remaining area was mowed with a riding mower and all clippings were removed from the plot. Fresh clippings were dried for $4 \mathrm{~d}$ at $60^{\circ} \mathrm{C}$, and yield data were calculated on a dry weight basis. The dry matter yield data are the 
sums of twelve individual harvests. Clippings were collected from May to October 2004. An assessment of turf height was carried out by placing a measuring scale on the ground and measuring the height of the leaf from the ground surface. Turf height was measured during April 2004 before mowing the plots. Twenty-five measurements were made within each plot and the mean value was calculated.

A visual assessment of turf color was carried out twice between May to September 2004. Scoring was done on a scale of 1 to 10 , with a score of 1 indicating brown turf, 5 indicating a moderate green color, and 10 indicating a very dark green color.

Straw was used to cover the seeded plots to protect turf seeds from predators like birds, deer etc. Wheat counts were also recorded before removing them manually. Wheat counts were counted within $10 \mathrm{~cm} \times 10 \mathrm{~cm}$ grid area placed randomly at four different locations in each plot.

\subsubsection{Evaluation of Weed Counts}

The competitive ability of the turfgrass to suppress weed germination was monitored by taking weed counts of natural weed population and weed seedlings emerged after manually seeding the weed seeds. For this purpose, seeds of black medic [Medicago lupulina], large crabgrass [Digitaria sanguinalis L.], green foxtail [Setaria viridis L.], London rocket [Sisymbrium irio], white clover [Trifolium repens L.], and witchgrass [Panicum capillare L.] were seeded linearly in rows across all plots, one row for each species at a distance of $0.30 \mathrm{~m}$. Weed seeding was done manually in June 2004 after the turf was established at approximately 500 weed seed/plot for each species. Weed dynamics of natural species were monitored during May and September 2004 to 
determine differences between weed densities in various treatments. Weed counts of seeded weeds were recorded in September 2004.

\subsubsection{Greenhouse Study and Evaluation of Turfgrass Root Depth}

Greenhouse experiments were established in fall 2004. These studies were designed to determine the effects of CPL on turfgrass root growth. Containers $(20.3 \mathrm{~cm}$ in height and $12.7 \mathrm{~cm}$ in diameter) were filled 3/4 with air-dried subsoil collected from the field experiments site. Treatments included control plots with no compost; fertilizer (20-27-5) applied at the rate of $454 \mathrm{Kg} \mathrm{ha}^{-1}$; and 10\%, 20\%, 40\% compost (v/v), and equivalent to $43750 \mathrm{Kg} \mathrm{ha}{ }^{-1}, 8.75^{*} 10^{4} \mathrm{Kg} \mathrm{ha}^{-1}$, and $1.75^{*} 10^{5} \mathrm{Kg} \mathrm{ha}^{-1}$, respectively. Composted poultry litter was incorporated to a depth of $12.7 \mathrm{~cm}$ at different rates. On August 2004, all containers were seeded manually with Kentucky bluegrass (Scotts 'Classic'; Kentucky bluegrass $97.75 \%, 0.05 \%$ other crop seeds, $2.11 \%$ inert matter, 0.09 weed seed) seeds at the rate of $454 \mathrm{Kg} \mathrm{ha}^{-1}$. Containers were irrigated prior to seeding. Containers were then covered with straw mulch and irrigated daily until seeds germinated, after which containers were watered on an as needed. Kentucky bluegrass was allowed to establish for a period of 6 months, under natural light and temperature ranging between $18^{\circ} \mathrm{C}(\min )$ to $35.5^{\circ} \mathrm{C}(\max )$. Supplemental heat was provided during winter to maintain the temperature at $18^{\circ} \mathrm{C}$. Turf was maintained at a mowing height of $7.6 \mathrm{~cm}$ using a pair of clippers and dry clippings weights were recorded. In February 2005 , the study was terminated to observe root depth. Containers were saturated $1 \mathrm{~h}$ prior to separating the container from the soil/root mass. Containers were placed upside down and tapped gently to remove the soil and root mass. Soil mass containing roots was then sliced lengthwise into halves from the middle, and the roots were exposed. A 
measuring scale was placed along the side of soil mass and presence/absence of roots was observed at $1 \mathrm{~mm}$ increments to a depth of $10 \mathrm{~cm}$.

\subsubsection{Experimental Design and Statistical Analysis}

Field and greenhouse experiments were set as a randomized complete block design with two factors. In field experiment, type of turf (seeded/sodded) served as the main factor and compost incorporation served as a sub factor. The treatments were replicated four times. Analysis of variance was used to analyze the data using PROC $\mathrm{GLM}^{\mathrm{TM}}$ (general linear models) procedure of the Statistical Analysis System (SAS Institute, 2002). The least significant difference (LSD) method, with a probability value of 0.05 , was used to separate treatment means. Correlation analysis was performed (using Sigma $\mathrm{Plot}^{\mathrm{TM}}, 8.2$ ) between turfgrass root depth and clippings dry weight.

\subsection{Results and Discussion}

In these experiments, significant effects $(p>0.001)$ of percent compost were observed on clipping dry weight, seedling height, visual color ratings, turf root growth, and total weed count (Table 4.2).

\subsubsection{Dry Matter Yield}

Turfgrass growth, as measured by clipping dry weight, was found to be greater for compost amended plots (Fig. 4.1) than control and fertilizer plots. Positive linear relationship was observed between compost application rates and yield of Kentucky bluegrass (sodded, $\mathrm{R}^{2}=0.92$; seeded, $\mathrm{R}^{2}=0.99$ ). Dry weights of clippings from seeded and sodded plots increased by approximately 500\% and 300\% respectively with the application of $40 \%$ compost (Fig. 4.1). Turfgrass yield was higher in sodded plots as compared to seeded plots. This is explained by the well-established turf in sodded plots 
as compared to newly germinated seedling in seeded turf. Enhanced growth of turfgrass in compost-amended plots is attributed to the overall effect of compost on soil physical and chemical properties (Mandal et al., 2005). In compost amended plots, the higher amount of available nutrients $(\mathrm{N}, \mathrm{P}, \mathrm{Ca}, \mathrm{Mg}$, and $\mathrm{K})$ coupled with the increase in $\mathrm{CEC}$ improved the fertility status of the subsoil. In this study, the addition of compost increased the total $\mathrm{N}$ content of soils especially since compost had a low C:N ratio (10:1) and a high rate of mineralization (Havlin et al., 1999). Landschoot and McNitt (1994b) and Gentilucci et al. (2001) attributed the poor establishment in turf following the addition of compost with high $\mathrm{C}: \mathrm{N}$ ratio (>30:1) to increased rates of immobilization and denitrification. Moreover, the addition of CPL increased soil $\mathrm{pH}$ from 5.9 (control) to 7.4 (40\% compost) making it ideal for turfgrass establishment (Landschoot and McNitt, 1994a; Maynard, 1993). Others have also reported increases in the yield of crops (peanut and corn) following PL application (Balkcom et al., 2003; Cooperband et al., 2002). Wood et al., (1993) observed $556 \%$ increase in bermudagrass yields with $224 * 10^{2} \mathrm{Kg}$ ha $^{-1}$ PL application compared to control. Lucero et al. (1995) observed curvilinear increase in the yields of the blend of Kentucky bluegrass and tall fescue with increasing rates of PL. Loschinkohl and Boehm (2001) observed 244\% increase in dry clippings weight with $148 \mathrm{Kg} \mathrm{ha}^{-1}$ and $43 \mathrm{Kg} \mathrm{ha}^{-1}$ turfgrass yield in compost-treated and control plots respectively (collected from an area of $0.85 \mathrm{~m}^{-2}$ ). This corroborates with the current work where an increase of $318 \%$ in dry clippings weight with $1780 \mathrm{Kg} \mathrm{ha}^{-1}$ and $424 \mathrm{Kg}$ $\mathrm{ha}^{-1}$ (from an area of $3.2 \mathrm{~m}^{2}$ ) turfgrass yield in $40 \%$ compost-treated and control plots was observed. 
Table 4.2 Analysis of variance for dry matter, seedling height, visual color rating, and total weed count

\begin{tabular}{|c|c|c|c|c|c|c|}
\hline Sources of Variation & $\mathrm{n}$ & $\begin{array}{l}\text { Dry } \\
\text { matter }\end{array}$ & $\begin{array}{l}\text { Seedling } \\
\text { height }\end{array}$ & $\begin{array}{l}\text { Visual } \\
\text { color } \\
\text { rating }\end{array}$ & $\begin{array}{l}\text { Visual } \\
\text { color } \\
\text { rating }\end{array}$ & $\begin{array}{c}\text { Total } \\
\text { weed } \\
\text { count }\end{array}$ \\
\hline & & & & $\underline{\mathrm{P}>\mathrm{F}}$ & & \\
\hline Control vs Others & 1 & $* * *$ & NS & $*$ & $* * *$ & NS \\
\hline Fertilizer vs Compost & 1 & $* * *$ & $* * *$ & $* * *$ & $* * *$ & NS \\
\hline $\mathrm{C} 10$ vs $\mathrm{C} 20, \mathrm{C} 40$ & 1 & $* * *$ & NS & $* *$ & $* * *$ & $*$ \\
\hline C20 vs C40 & 1 & $* * *$ & NS & NS & NS & NS \\
\hline $\begin{array}{c}\text { Turf type x Control vs } \\
\text { Others }\end{array}$ & 1 & NS & NS & $* *$ & NS & NS \\
\hline $\begin{array}{c}\text { Turf type } \mathrm{x} \text { Fertilizer vs } \\
\text { Compost }\end{array}$ & 1 & NS & NS & NS & $* *$ & NS \\
\hline $\begin{array}{c}\text { Turf type x C10 vs C20, } \\
\text { C40 }\end{array}$ & 1 & NS & NS & $*$ & NS & $*$ \\
\hline Turf type x C20 vs C40 & 1 & NS & NS & NS & NS & NS \\
\hline
\end{tabular}

* Significant at 0.05 probability level

** Significant at 0.01 probability level

*** Significant at 0.001 probability level

$\dagger$ readings taken in May 2004

† readings taken in September 2004 


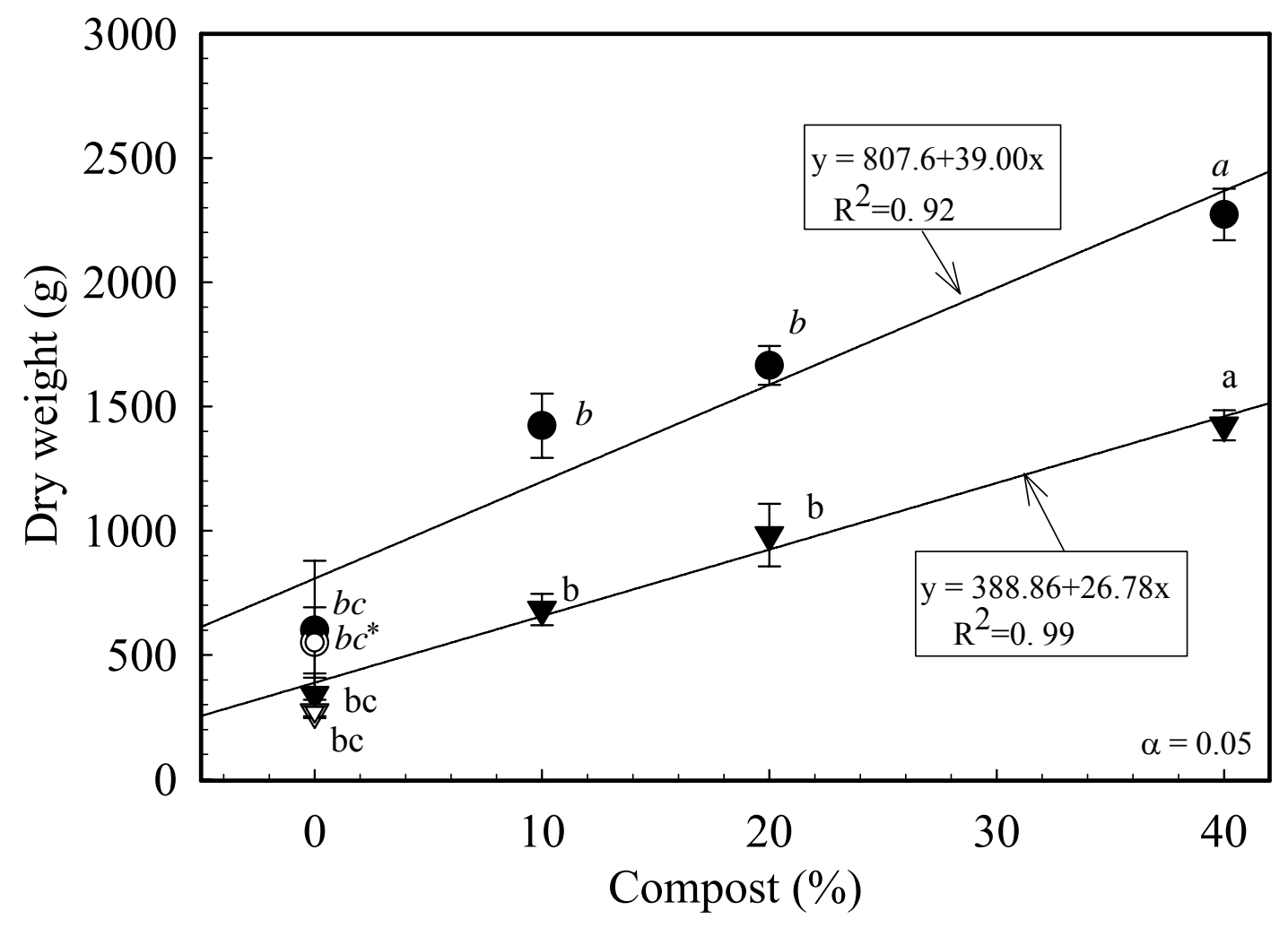

Fig. 4.1 Effect of incorporating composted poultry litter into top $16 \mathrm{~cm}$ of subsoil on Kentucky bluegrass clipping yield (dry matter) for $\bullet$ sodded compost; o sodded fertilizer; $\boldsymbol{\nabla}$ seeded compost; and $\nabla$ seeded fertilizer plots.

* Means with same letters are statistically insignificant at $p<0.05$

Lower turfgrass yield was recorded in fertilized plots as compared to control. This low turf establishment is explained by the lower soil $\mathrm{pH}$ resulting from the application of $\mathrm{NH}_{4}-\mathrm{N}$ fertilizers and its effect on the availability of plant nutrients. Rasnake and Murdock (2002) also reported a decrease in tall fescue yield due to decrease in $\mathrm{pH}$ with $\mathrm{N}$ application on a silt loam soil. 
Total wheat counts also increased with increasing rates of compost application (Table 4.3) further illustrating the positive effects of compost on soil physical and chemical properties.

Table 4.3 Wheat density per $0.36 \mathrm{~m}^{2}$

\begin{tabular}{cc}
\hline Treatments & Total wheat counts \\
\hline $40 \%$ Compost & 34 \\
20\% Compost & 22 \\
10\% Compost & 17 \\
Fertilizer & 16 \\
Control & 9 \\
\hline
\end{tabular}

\subsubsection{Turf Cover}

All compost treated plots showed 50\% higher turf cover (as determined by percent bare spots) than control plots on 11 April 2004 (Fig. 4.2). Fertilized plots showed $20 \%$ more bare area as compared to the control plots. Significant improvements in turf cover were observed during the second measurement (1 September, 2004). The high turf cover in compost treated plots $(100 \%$ turf cover) as opposed to fertilized plots $(76 \%)$ is attributed to CPL addition. Compost incorporation improved soil physical properties but decreased water available capacity, thus better turf establishment is mainly attributed to the increase in soils mineral nutrient content (Mandal et al., 2005) and not on water available capacity. In this study, no significant differences among various compost rates were recorded (Fig. 4.2), indicating that 10\% compost application was most efficient in achieving healthy turf. Our results agree with those of Lawson (2002) who reported increase in turf cover following compost application. 
A positive linear relationship $\left(\mathrm{R}^{2}=0.99\right)$ was observed between compost rates, and seedling density (Fig. 4.3). Based on our regression model, it was estimated that $10 \% \mathrm{CPL}$ applied to disturbed soils resulted in at least 70 seedlings per $7.6 \mathrm{~cm}^{2}$, which was sufficient to attain $100 \%$ turf cover. Turf cover as measured by counting seedling number showed linear increase in seedling density with compost rates, whereas turf cover as measured by percent bare area showed increases in turf cover from control to $20 \%$ compost after which it plateaued. There was a strong positive correlation $(\rho=0.80)$ between the two variables indicating that seedling density may be used to predict turf cover. 


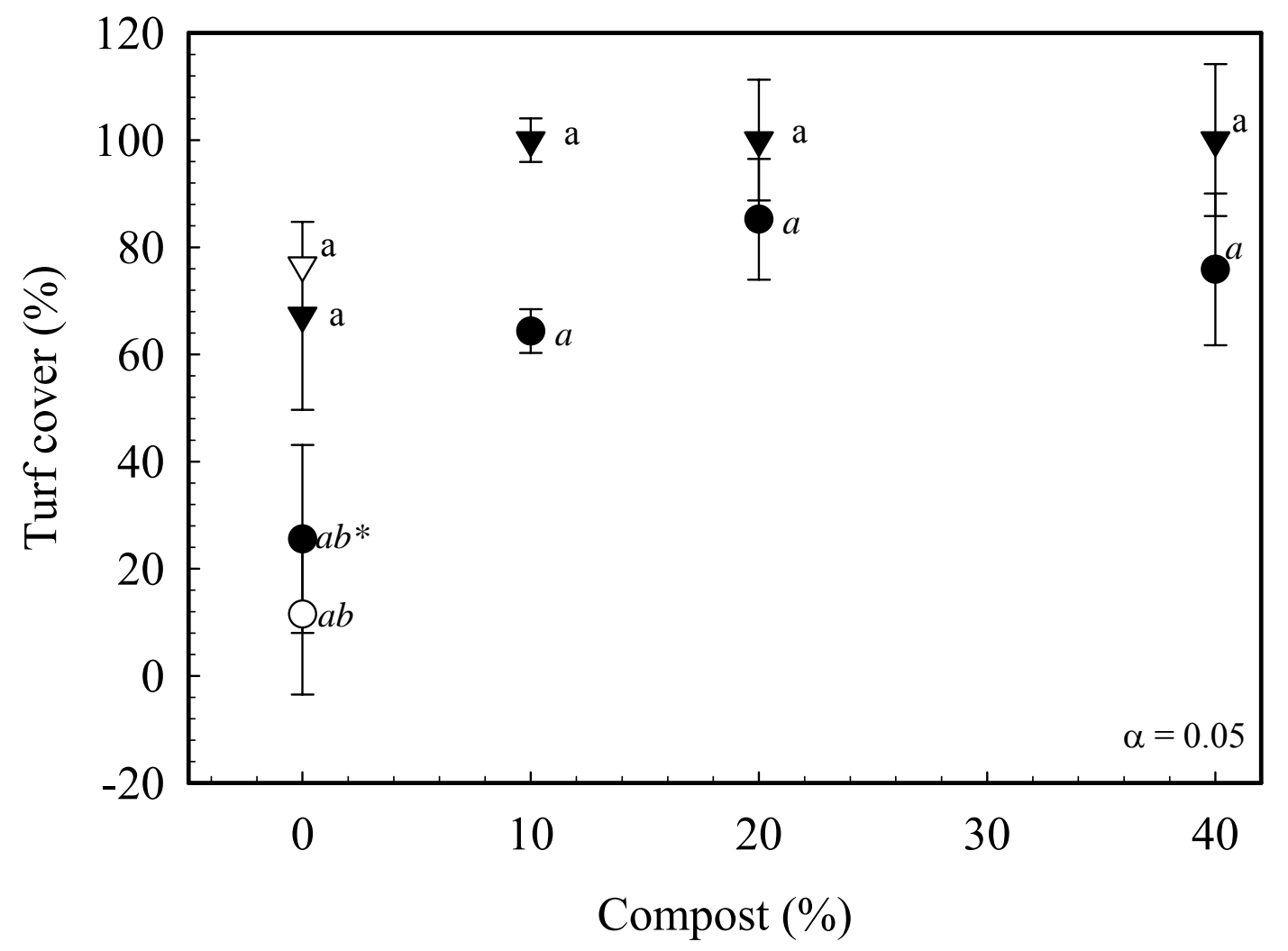

Fig. 4.2 Effect of incorporating composted poultry litter into top $16 \mathrm{~cm}$ of sunsoil on seeded Kentucky bluegrass cover for $\bullet$ April - seeded, compost; o April- fertilizer; $\boldsymbol{\nabla}$ Sept. - seeded, compost; and $\nabla$ Sept. - fertilizer.

* Means with same letters are statistically insignificant at $p<0.05$ 


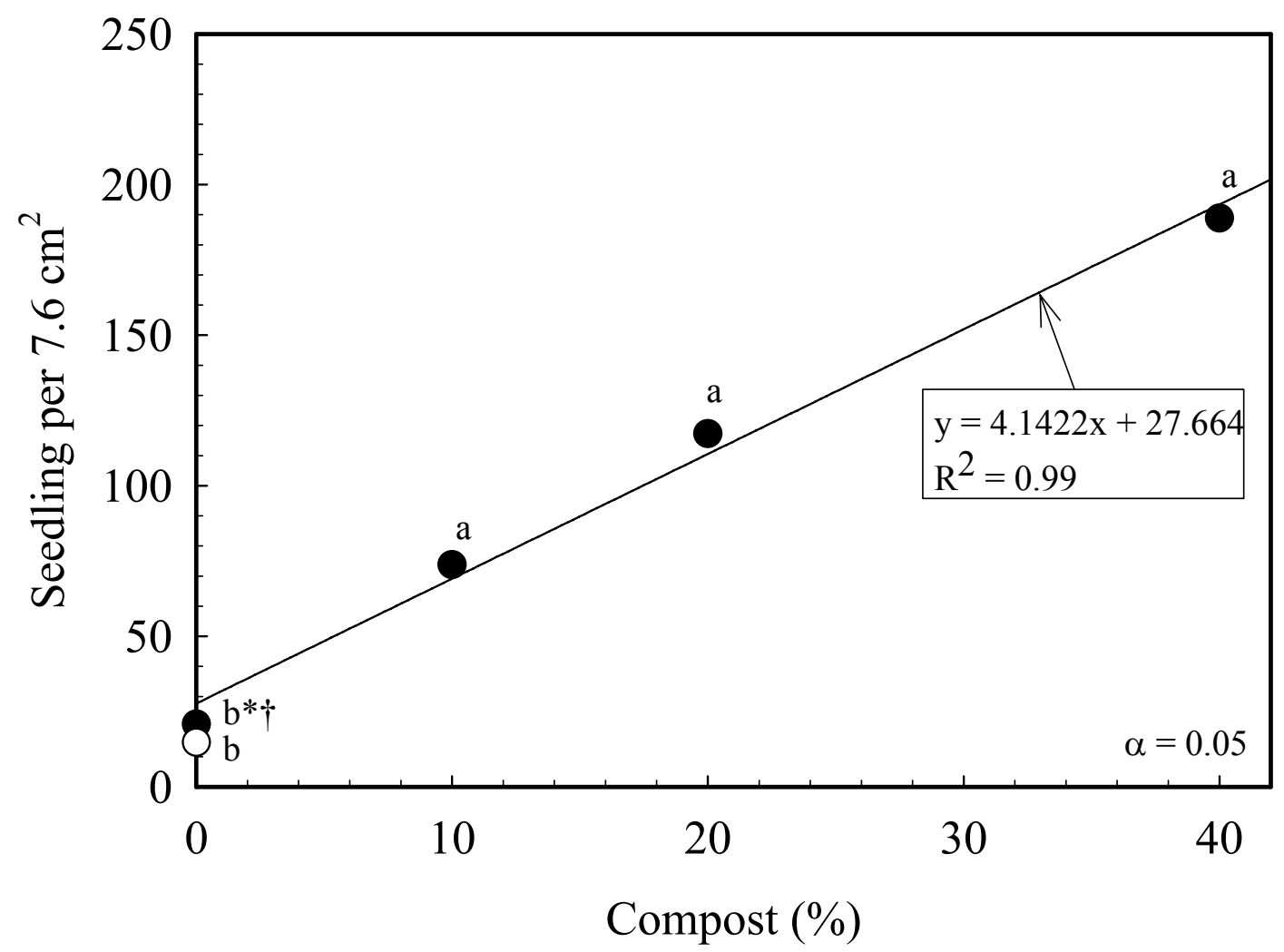

Fig. 4.3 Effect of incorporating composted poultry litter into top $16 \mathrm{~cm}$ of subsoil on Kentucky bluegrass seedling density.

* Means with same letters are statistically insignificant at $p<0.05$

$\dagger$ values for standard error were small ranging between 0.21 (min.) to 0.82 (max.) and hence are not shown in figure. 
It is important to note that for seeded plots, the turfgrass growth increased in summer as opposed to fall, and took an average of one year for full turfgrass establishment on disturbed soils amended with compost, regardless of compost application rate. The poor turf cover (as determined by percent bare spots and seedling density) observed in fertilized plots (as compared to control plots) may be related to the acidifying effects of fertilizer used (Mandal et al., 2005).

\subsubsection{Turf Color}

Turf color ratings were conducted twice in 2004 (May and August). On May 2004, compost-treated turf showed significantly higher color ratings compared to both control and fertilized plots in sodded treatments but not in seeded treatments (Fig. 4.4). The second color rating taken on 26 August 2004 indicated that all compost treated plots were greener in color than untreated plots (Fig. 4.5). The most desirable turf color (dark green) was observed in plots with $20 \%$ and $40 \%$ compost rates. Better color of compost treated plots compared to fertilized plots, may be attributed to the difference in the higher amount of $\mathrm{N}$ in compost as well as its ability to increase the availability of micronutrients especially $\mathrm{Fe}^{2+}$ through chelation (Stevenson, 1982). The ability of compost to enhance the turf color was also reported by other researchers (Garling and Boehm, 2001; Lawson 2002; Schumann et al., 1993; and Strange et al., 1998). The mechanisms responsible for this effect were not clear. 


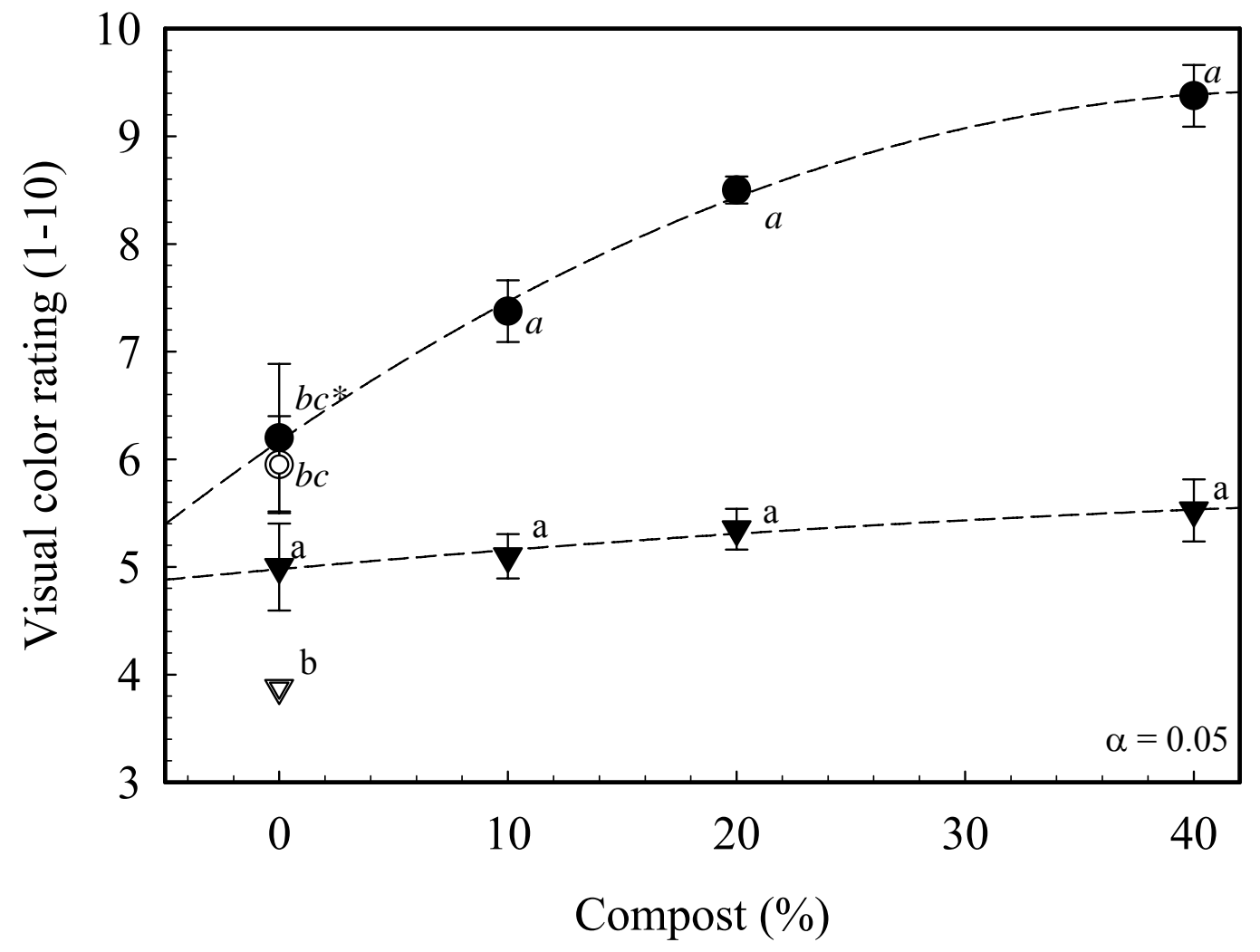

Fig. 4.4 Effect of incorporating composted poultry litter into top $16 \mathrm{~cm}$ of subsoil on Kentucky bluegrass color $\bullet$ sodded compost - May; o sodded fertilizer - May; $\boldsymbol{\nabla}$ seeded compost - May.; and $\nabla$ seeded fertilizer - May.

* Means with same letters are statistically insignificant at $p<0.05$ 


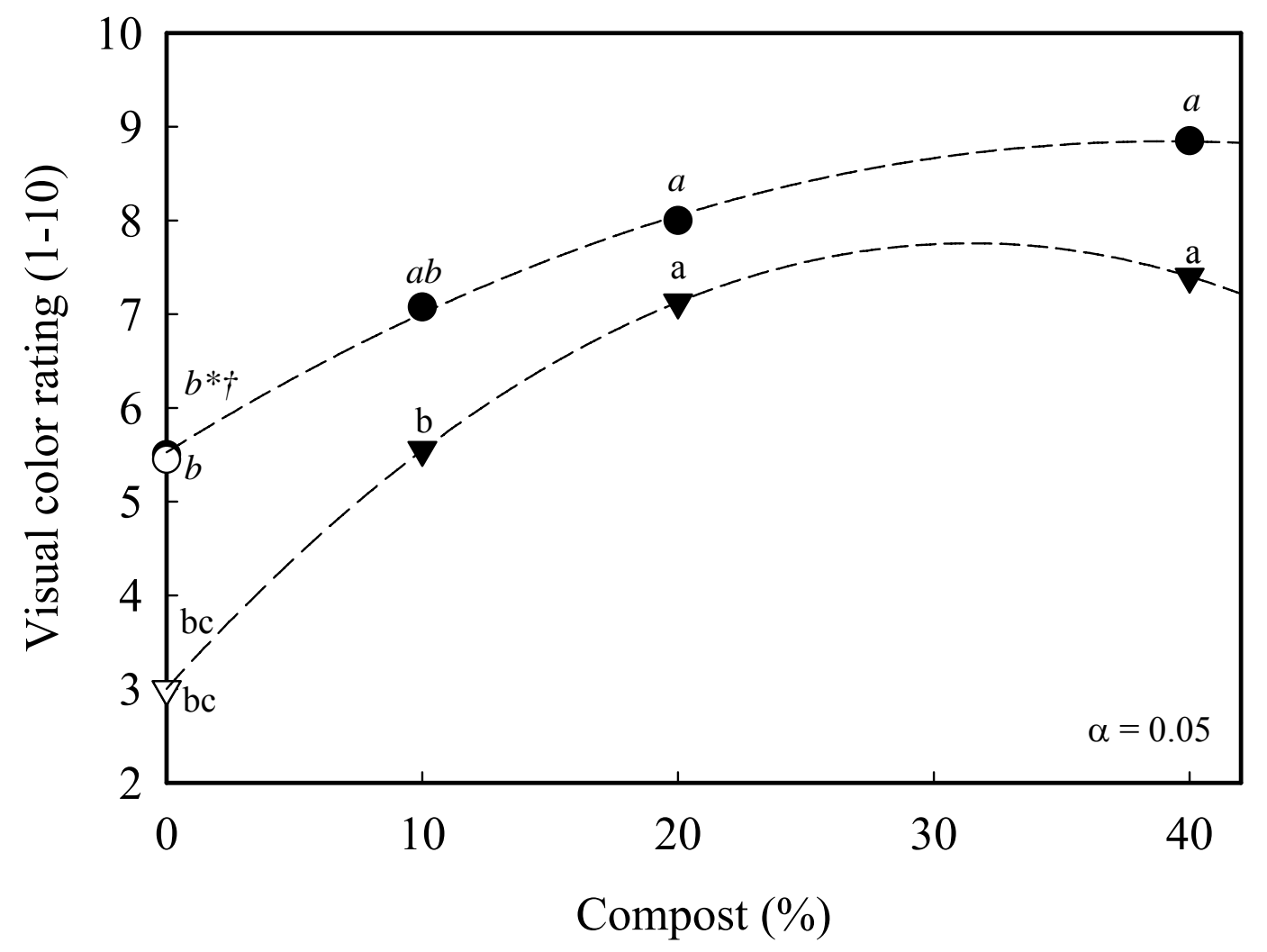

Fig. 4.5 Effect of incorporating composted poultry litter into top $16 \mathrm{~cm}$ of subsoil on Kentucky bluegrass color - sodded compost - September; o sodded fertilizer September; $\boldsymbol{\nabla}$ seeded compost - September; and $\nabla$ seeded fertilizer - September

* Means with same letters are statistically insignificant at $p<0.05$

$\dagger$ values for standard error were small ranging between 0 (min.) to 0.59 (max.) and hence are not shown in figure. 


\subsubsection{Turf Height}

Turf height was measured for both seeded and sodded plots during April 2004, prior to mowing. Turf height was not affected by the various treatments during periods of active growth (Table 4.4). In sodded plots, turf height was higher in compost treated plots than control or fertilized plots (Table. 4.4). This increase in turf height is explained by the better establishment of turf in compost-treated plots. Both seeded and sodded fertilized plots showed $30 \%$ and $8 \%$ lower turf height than control plots, respectively (Table 4.4). This effect was attributed to lower $\mathrm{pH}$ and organic matter in fertilized plots and their subsequent effects on turf growth and establishment (Mandal et al., 2005a).

Table 4.4 Effect of different treatments on seeded and sodded turf height

\begin{tabular}{ccc}
\hline Treatments & Seeded & Sodded \\
\hline & $--------------c m-------------$ \\
$40 \%$ compost & $7.18^{\mathrm{a}^{*}}$ & $10.36^{\mathrm{a}}$ \\
$20 \%$ compost & $7.64^{\mathrm{a}}$ & $9.04^{\mathrm{a}}$ \\
$10 \%$ compost & $5.49^{\mathrm{a}}$ & $9.41^{\mathrm{a}}$ \\
Fertilizer & $4.37^{\mathrm{ab}}$ & $5.8^{\mathrm{b}}$ \\
Control & $6.27^{\mathrm{a}}$ & $6.33^{\mathrm{ab}}$ \\
\hline
\end{tabular}

* Different letters in the same column indicate a significant difference at $p<0.05$

\subsubsection{Weed Populations}

Weeds were counted twice in May and September 2004. In May 2004, no weeds were observed. Weeds were present in both sodded and seeded plots in September 2004 (Table 4.5). The most dominant weed species were white clover [Trifolium repens] and dandelion [Taraxacum officinale] followed by buckhorn plantain [Plantago lanceolata], red clover [Trifolium pratense], yellow woodsorrel [Oxalis stricta], large crabgrass 
[Digitaria sanguinalis], and wild carrot [Daucus carota]. In seeded plots, individual weed counts as well as total weed counts were found to decrease with increasing rates of compost, whereas no differences in weed counts were observed between control and fertilized plots (same trend in weed counts were recorded in sodded composted plots).

Table 4.5 Number of weeds in seeded and sodded plots

\begin{tabular}{ccccccc}
\hline Treatments & $\begin{array}{c}\text { White } \\
\text { clover }\end{array}$ & Dandelion & $\begin{array}{c}\text { Buckhorn } \\
\text { plantain }\end{array}$ & $\begin{array}{c}\text { Red } \\
\text { clover }\end{array}$ & $\begin{array}{c}\text { Yellow } \\
\text { woodsorrel }\end{array}$ & $\begin{array}{c}\text { Total } \\
\text { weed } \\
\text { count }\end{array}$ \\
\hline \multicolumn{7}{c}{ Seeded } \\
$40 \%$ Compost & $26^{\mathrm{bc} c^{*}}$ & $67^{\mathrm{a}}$ & $8^{\mathrm{bc}}$ & $2^{\mathrm{b}}$ & $0^{\mathrm{a}}$ & $33^{\mathrm{b}}$ \\
$20 \%$ Compost & $172^{\mathrm{b}}$ & $147^{\mathrm{a}}$ & $79^{\mathrm{b}}$ & $21^{\mathrm{ab}}$ & $0^{\mathrm{a}}$ & $112^{\mathrm{ab}}$ \\
$10 \%$ Compost & $265^{\mathrm{a}}$ & $198^{\mathrm{a}}$ & $132^{\mathrm{b}}$ & $115^{\mathrm{a}}$ & $14^{\mathrm{a}}$ & $193^{\mathrm{a}}$ \\
Fertilizer & $135^{\mathrm{b}}$ & $1^{\mathrm{a}}$ & $238^{\mathrm{a}}$ & $33^{\mathrm{ab}}$ & $3^{\mathrm{a}}$ & $108^{\mathrm{ab}}$ \\
Control & $124^{\mathrm{b}}$ & $45^{\mathrm{a}}$ & $240^{\mathrm{a}}$ & $73^{\mathrm{a}}$ & $3^{\mathrm{a}}$ & $120^{\mathrm{a}}$
\end{tabular}

\section{$\underline{\text { Sodded }}$}

\begin{tabular}{ccccccc}
$40 \%$ Compost & $12^{\mathrm{a}}$ & $148^{\mathrm{a}}$ & $0^{\mathrm{a}}$ & $1^{\mathrm{a}}$ & $7^{\mathrm{b}}$ & $42^{\mathrm{a}}$ \\
$20 \%$ Compost & $1^{\mathrm{a}}$ & $101^{\mathrm{ab}}$ & $0^{\mathrm{a}}$ & $13^{\mathrm{a}}$ & $17^{\mathrm{b}}$ & $36^{\mathrm{a}}$ \\
$10 \%$ Compost & $10^{\mathrm{a}}$ & $121^{\mathrm{a}}$ & $1^{\mathrm{a}}$ & $3^{\mathrm{a}}$ & $3^{\mathrm{b}}$ & $38^{\mathrm{a}}$ \\
Fertilizer & $10^{\mathrm{a}}$ & $311^{\mathrm{a}}$ & $6^{\mathrm{a}}$ & $4^{\mathrm{a}}$ & $104^{\mathrm{a}}$ & $114^{\mathrm{a}}$ \\
Control & $6^{\mathrm{a}}$ & $284^{\mathrm{a}}$ & $11^{\mathrm{a}}$ & $8^{\mathrm{a}}$ & $5^{\mathrm{b}}$ & $80^{\mathrm{a}}$ \\
\hline
\end{tabular}

* Different letters in the same column indicate a significant difference at $p<0.05$

$\dagger$ Total weed count done in September 2004

The subsoil initially has less weed seed bank as compared to the topsoil. Total absence or limited presence of a weed seed bank reduces weed infestations in newly established turfgrass considerably (Ashton and Monaco, 1991). Amending subsoil with compost resulted in better turf establishment, which consequently gave rise to healthy and well established turf, able to out-compete weeds and other pests. In general, compost treatments were able to keep weeds at lower levels than control and fertilizer plots, and simultaneously maintain good turf quality ratings. Others have also observed similar 
results of weed suppression by compost application (Ozores-Hampton et al., 2001; Preusch and Tworkoski, 2002; Stratton and Reichcigl (1998).

Out of six manually seeded weed species, only large crabgrass germinated in most of the plots. Occasional growth of black medic was observed. Inconsistent behavior of seeded weeds was observed in seeded and sodded plots treated with compost. In sodded turf, fewer weeds occurred in compost plots then control plots (Table 4.6). In seeded turf, more weeds were observed. Fertilized sodded and seeded turf had more crabgrass counts than the control turf.

Table 4.6 Total number of manually seeded weed species

\begin{tabular}{cccc}
\hline Treatments & Large crabgrass & Black medic & Total weed count \\
\hline & Seeded & & \\
$40 \%$ Compost & 128 & 0 & $128^{\mathrm{a}^{*}}$ \\
$20 \%$ Compost & 35 & 0 & $42^{\mathrm{ab}}$ \\
$10 \%$ Compost & 0 & 72 & $72^{\mathrm{a}}$ \\
Fertilizer & 0 & 49 & $49^{\mathrm{ab}}$ \\
Control & 0 & 0 & $0^{\mathrm{b}}$ \\
& $\underline{\text { Sodded }}$ & & \\
$40 \%$ Compost & 48 & 0 & $48^{\mathrm{b}}$ \\
$20 \%$ Compost & 34 & 0 & $34^{\mathrm{b}}$ \\
$10 \%$ Compost & 32 & 21 & $32^{\mathrm{b}}$ \\
Fertilizer & 128 & 0 & $128^{\mathrm{a}}$ \\
Control & 102 & $03^{\mathrm{a}}$ \\
\hline
\end{tabular}

* Different letters in the same column indicate a significant difference at $p<0.05$

\subsubsection{Greenhouse Experiments}

Turfgrass root depth, as measured by observing presence/absence of roots at every $1 \mathrm{~mm}$ increment up to $10 \mathrm{~cm}$, was found to increase linearly $\left(\mathrm{R}^{2}=0.89\right)$ with increasing rates of compost (Fig. 4.6). Clippings dry weights also increased with compost rates (Table 4.6). 
These results correlate well with data reported by Chandran (1993). A positive correlation existed between root depth and clippings dry weight $(r=0.94)$ (Fig. 4.7), indicating well-established and deep root system. Dry clippings weight increased linearly with increasing root depth at different compost application rates. No germination of Kentucky bluegrass seeds in fertilized containers further stress the acidifying effect of fertilizer on turfgrass establishment.

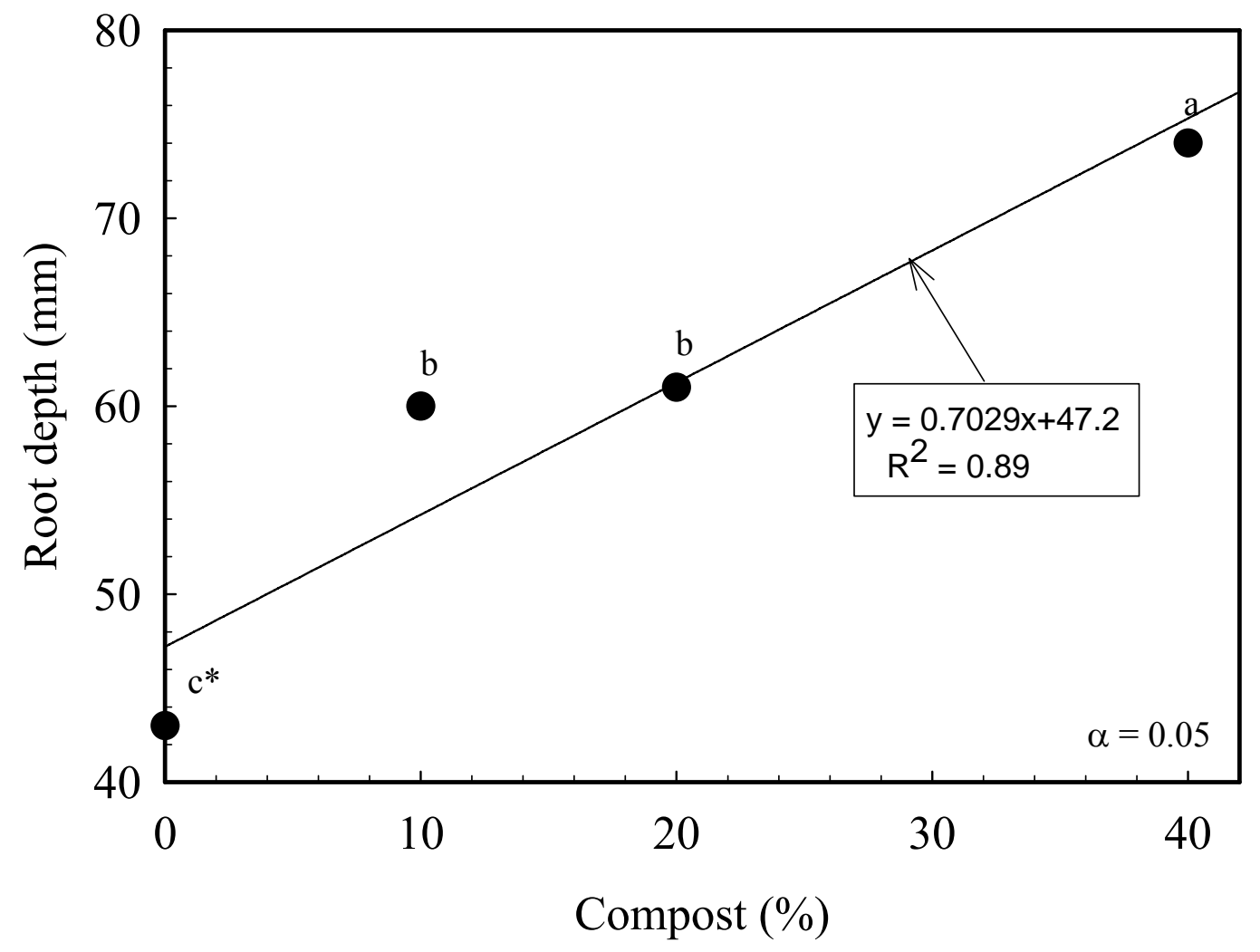

Fig. 4.6 Effect of incorporating composted poultry litter into subsoil on Kentucky bluegrass root depth 


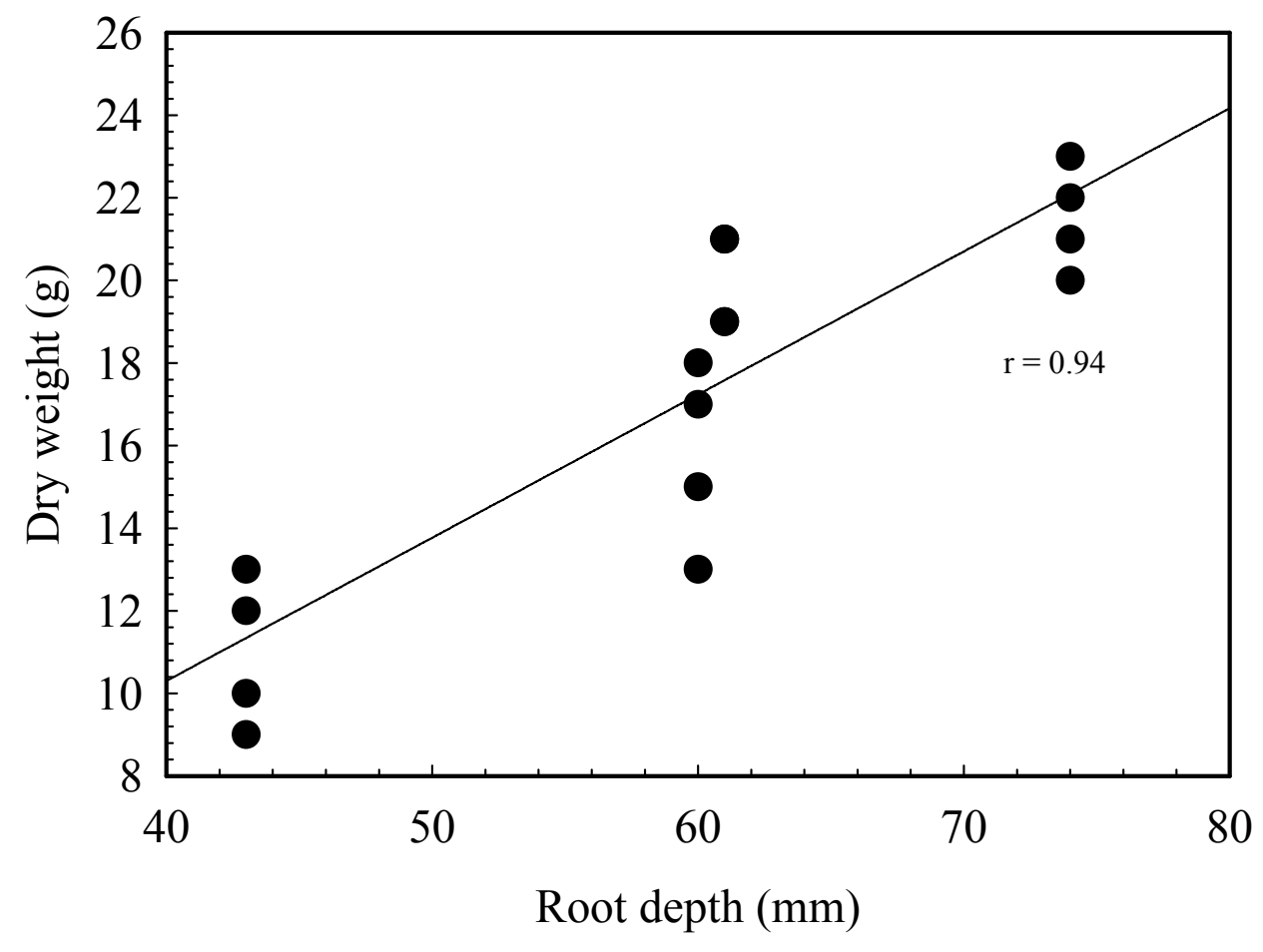

Fig. 4.7 Correlation analysis between turfgrass root depth and dry clipping weight

Table 4.7 Effect of different treatments on dry clippings weight (greenhouse experiments)

\begin{tabular}{cc}
\hline Treatments & $\begin{array}{c}\text { Mean dry clipping } \\
\text { weight }(\mathrm{g})\end{array}$ \\
\hline & \\
$40 \%$ compost & 23 \\
$20 \%$ compost & 19 \\
$10 \%$ compost & 12 \\
Fertilizer & 0 \\
Control & 9 \\
\hline
\end{tabular}




\subsection{Conclusions}

This study has demonstrated that CPL can be used to enhance the establishment and growth of turfgrass on disturbed soils. This is of particular benefit for the establishment of new lawns on nutrient deficient soils where erosion is likely when turf is slow to establish. Compost applications resulted in an improvement in turf quality, growth, and establishment, as well as deeper root system. Although high quality turfgrass ratings and low weed populations were obtained when $40 \%$ compost amendment was applied, $10 \%$ compost application was most efficient for establishment of healthy turf. No deleterious effects of compost on turfgrass quality were observed, even at the highest compost application rate of $40 \%(\mathrm{v} / \mathrm{v})$.

These results also demonstrate reduced number of weeds by incorporation of CPL into the soil profile. The use of composts to improve the establishment and quality of turfgrasses and to control weeds can prove to be an environmentally safe alternative for the disposal of an ever increasing amount of urban solid wastes. 


\section{Summary}

In this study, CPL incorporation into subsoil significantly enhanced turfgrass establishment and growth while improving the disturbed silt loam soil physical and chemical properties. The amount and composition of organic matter added to the subsoil affected the extent to which its physical and chemical properties were modified. As the rate of CPL addition increased, soil water content, organic matter, $\mathrm{pH}, \mathrm{CEC}$, and mineral nutrient content increased whereas its bulk density and available water content decreased. In general, CPL enhanced the establishment and growth of turfgrass on disturbed soil by improving the turf color and its percent cover. CPL also induced a deeper root system growth and reduced the total number of weeds germinated. Although high quality turfgrass ratings and low weed populations were obtained when $40 \%$ compost was applied, $10 \%$ compost application was judged most efficient for the establishment of healthy turf. No deleterious effects of compost on turfgrass quality were observed, even at the highest compost application rate of $40 \%(\mathrm{v} / \mathrm{v})$. These results demonstrate that CPL can be used to enhance the soil physical and chemical properties of eroded or disturbed soils. This is of particular benefit for the establishment of new lawns on nutrient deficient soils where erosion is likely and when turf is slow to establish. Laboratory experiments showed suppression of various weed seeds germination by composted poultry litter extract. In these experiments all the weed species were found to be sensitive to compost extract except barnyardgrass, which was most resistant to compost extract.

Our results suggest that CPL can be used as a part of integrated pest management programs that reduces pesticides application while providing effective weed control method. Amending soils with organic wastes can have two advantages; managing the 
disposal problem and improving the soil nutrient and organic matter content especially for agricultural soils with low fertility. 


\section{References}

Aggelides, S.M. and P.A. Londra. 2000. Effects of compost produced from town wastes and sewage sludge on the physical properties of a loamy and a clay soil. Bioresource technology. 71:253-259.

Angle, J.S., D.C. Wolf, and J.R. Hall III. 1981. Turfgrass growth aided by sludge compost. BioCycle. Novmember/December:40-43.

Ashton, F.M. and T.J. Monaco. 1991. Weed Science: Principle and Practices. New York: John Wiley \& Sons Inc, pp 393-403.

Avimelech, A., A. Cohen, and D. Shkedi. 1990. The effect of municipal solid waste compost on the fertility of clay soils. Soil Tech. 3:275-284.

Balkcom, K. S., J. F. Adams, and D. L. Hartzog. 2003. Peanut yield response to poultry litter and municipal sludge application. Commun. Soil Sci. Plant Anal. 34:801814.

Bevacqua, R.F. and V.J. Mellano. 1993a. Sewage sludge compost's cumulative effects on crop growth and soil properties. Compost Science \& Utilization. Summer:34-37.

Bevacqua, R.F., and V.J. Mellano. 1993b. Sludge compost boosts yields of California crops. BioCycle. 34:78-79.

Bevacqua, R.F. and V.J. Mellano. 1994. Cumulative effects of sludge compost on crop yields and soil properties. Commun. Soil Sci. Plant Anal. 25:395-406. 
Boulter, J.I., G.J. Boland, and J.T. Trevors. 2000. Compost: A study of the development process and end-product potential for suppression of turfgrass disease. World Journal of Microbiology and Biotechnology. 16:115-134.

Boulter, J.I., G.J. Boland, and J.T Trevors. 2002. Evaluation of composts for suppression of dollar spot (Sclerotinia homoeocarpa) of turfgrass. Plant Disease. 86:405-410.

Buchanan, M. and S.R. Gliessman. 1991. How compost fertilization affects the soil nitrogen and crop yield. BioCycle. 32:72-77.

Chandran, R. S. 1993. Response of St. Augustinegrass to composted solid waste and irrigation frequency. M.S. Thesis. University of Florida.

Chandran, R.S. 2003. Integrated turfgrass weed management. Handbook of sustainable weed management, Haworth press, NY. chapter 23, pp 966

Chandran, R. S., J. F. Baniecki, A. Wilson, and M. Mandal. 2005. Susceptibility of Kentucky bluegrass of composted poultry litter to Drechslera leaf spot, Biological and Cultural Tests for Control of Plant Diseases. 20:C5

Chang, C. and H. H. Janzen. 1996. Long-term fate of nitrogen from annual feedlot manure applications. J. Environ. Qual. 25:785-790.

Chanysak, V., A. Katayana, M.F. Morai, S. Mori, and H. Kubota. 1983. Effects of compost maturity on growth of komatuna (Brassica rapa var. peudis) in Neubauer's pot II. Growth inhibitory factors and assessment of degree of maturity by org $\mathrm{C} /$ org $\mathrm{N}$ ratio of water extract. Soil Science and Plant Nutrition, 29:251-259. 
Clark, M.S., W.R. Horwath, C. Shennan, and K.M. Scow. 1998. Changes in soil chemical properties resulting from organic and low-input farming practices. Agron. J. 90:662-671.

Connell, D. W. 1997. Basic Concepts of Environmental Chemistry. Lewis Publisher, New York.

Cooperband, L., G. Bollero, and F. Coale. 2002. Effects of poultry litter and composts on soil nitrogen and phosphorus availability and corn production. Nutrient Cycling in Agroecosystems. 62:185-194.

Darmody, R.G., J.E. Foss, and M. McIntosh. 1983. Municipal sewage sludge compost amended soil: Some spatiotemporal treatment effects. J. Environ. Qual., 12:231-236.

DeVleeschauwer, D., O. Verdonck, and P. V. Assche. 1981. Phytotoxicity of refuse compost. BioCycle. 26:44-46.

Dick, W.A. and E.L. McCoy. 1993. Enhancing soil fertility by addition of compost. Science and Engineering of Composting. 623-643.

Dinelli, F.D. 1999. Using compost to improve turf ecology. USGA Green Section Record. July/August: 16-18.

Edwards, D.R. and T.C. Daniel. 1992. Environmental impacts of on-farm poultry waste disposal - A review. Bioresource Tech. 41:9-33

Eghball, B. 2002. Soil properties as influenced by phosphorus and nitrogen based manure and compost applications. Agron. J. 94:128-135. 
Epstein, E., J.M. Taylor, and R.L. Chaney. 1976. Effects of sewage sludge and sludge compost applied to soil on some soil physical and chemical properties. $J$. Environ. Qual. 5:422-426.

Evangelou, V. P. 1998. Soil minerals and their surface properties. In Environmental Soil and Water Chemistry-Principals and Applications. John Wiley \& Sons, Inc.

Gagnon, B. 2004. Contribution of on-farm and industrial composts to soil $\mathrm{pH}$ and enrichment in available nutrients and metals. Can. J. Soil Sci. 4:439-445.

Gagnon, B. and R. R. Simard. 1999. Nitrogen and phosphorus release from on-farm industrial composts. Can. J. Soil Sci. 78:207-215.

Gao, G. and C. Chang. 1996. Changes in CEC and particle size distribution of soils associated with long term annual applications of cattle feedlot manure. Soil Sci. 161:115-120.

Garling, D.C. and M.J. Boehm. 2001. Temporal effects of compost and fertilizer applications on nitrogen fertility of golf course turfgrass. Agron. J. 93:548555.

Gee, G. W. and J. W. Bauder. 1986. Particle-size analysis. In; Methods of Soil Analysis. Part 3. Chemical Methods-SSA Book Series no. 5. Soil Science Society of America and American Society of Agronomy. pp 383-409.

Gentilucci, G., J.A. Murphy, and D.E. Zaurov. 2001. Nitrogen requirement for Kentucky bluegrass grown on compost amended soil. International Turfgrass Society Research Journal. 9:382-387. 
Giusquiani, P.L., M. Pagliai, G. Gigliotti, D. Businelli, and A. Benetti. 1995. Urban waste compost: Effects on physical, chemical, and biological soil properties. J. Environ. Qual. 24:175-182.

Golstein, N. and R. Steuteville. 1995. Biosolids composting maintains steady growth. BioCycle. December:49-60.

Gouin, F.R. 1998. Commercial composting systems. HortScience. 33:932-933.

Gupta, G. and S. Charles. 1999. Trace elements in soils fertilized with poultry litter. Poultry Science. 78:1695-1698.

Hartz, T.K., F.J. Costa, and W.L. Schrader. 1996. Suitability of composted green waste for horticultural uses. HortScience. 31:961-964.

Havlin, J. L., J. D. Beaton, S. L. Tisdale, and W. L. Nelson. 1999. Soil Fertility and Fertilizers, An Introduction to Nutrient Management. Prentice Hall. Upper Saddle River, New Jersey.

Hillel, D. 2004. Introduction to Environmental Soil Physics. Elsevier Academic Press.

Hoitink, H.A.J. and M.J. Boehm. 1999. Biocontrol within the context of soil microbial communities: A substrate-dependent phenomenon, Annu. Rev. Phytopathology. 37:427-446.

Jamison, V. C. 1953. Changes in air-water relationships due to structural improvement of soils. Soil Sci. 76:143-151.

Jamison, V. C. and E. M. Kroth. 1958. Available moisture storage capacity in relation to textural composition and organic matter content of several Missouri soils. Soil. Sc. Soc. Am, Proc. 22:189-192. 
Kabir, M. E., M. A. Karim, and M. A. K. Azad. 2004. Effect of potassium on salinity tolerance of mungbean (Vigana radiate L. Wilczek). J. Bio Sc. 4(2):103-110.

Kelleher, B. P., J. J. Leahy, A. M. Henihan, T. F. O’Dwyer, D. Sutton, and M. J. Leahy. 2002. Advances in poultry litter disposal technology-a review. Bioresource Technology. 83:27-36.

Kiemnec, G.L., T.L. Jackson, D.D. Hemphill, and V.V. Volk. 1987. Relative effectiveness of sewage sludge as a nitrogen fertilizer for tall fescue. $J$. Environ. Qual. 16:353-356.

Klute, A. 1986. Water retention: laboratory methods. In; Methods of Soil Analysis. Part 3. Chemical Methods-SSA Book Series no. 5. Soil Science Society of America and American Society of Agronomy. pp 635-660.

Landschoot, P. and A. McNitt. 1994a. Improving turf with compost. BioCycle, October:54-57.

Landschoot, P. and A. McNitt. 1994b. Selecting composts to improve your turf. Turf Grass Trends. 3:1-5.

Landschoot, P. and D.V. Waddington. 1987. Response of turfgrass to various nitrogen sources. Soil Sci. Soc. Am. J. 51:225-230.

Larney, F.J. and H.H. Janzen. 1996. Restoration of productivity to a desurfaced soil with livestock manure, crop residue, and fertilizer amendments. Agron. J. $88: 921-927$.

Lawson, D. M. 2002. Compost application to football turf on an unamended soil rootzone. Journal of Turfgrass and Sports Surface Science. 78:71-76. 
Loschinkohl, C. and M.J. Boehm. 2001. Composted biosolids incorporation improves turfgrass establishment on disturbed urban soil and reduces leaf rust severity. HortScience. 36:790-794.

Lucero, D.W., D.C. Martens, J.R. McKenna, and D.E. Starner. 1995. Poultry litter effects on unmanaged pasture yield, nitrogen and phosphorus uptakes, and botanical composition. Commun. Soil Sci. Plant Anal. 26: 861-881.

MacRae, R. J. and G. R. Mehuys. 1985. Effect of green manuring on the physical properties of temperate area soils. In; B. A. Stewart (ed) Advances in Soil Science, Springer-Veriag, NY. pp 71-94.

Mandal, M. and R. S. Chandran. 2005. Compost as a soil conditioner and its effect on pest management and turfgrass growth. submitted to Compost Sci. Util.

Mandal, M., R. S. Chandran, and J. C. Sencindiver. 2005. Amending subsoil with composted poultry litter: effects on soil physical and chemical properties-II. Manuscript in preparation J. Environ. Qual.

Maynard, A.A. 1993. Evaluating the suitability of MSW compost as a soil amendment in field grown tomatoes. Compost Sci. \& Util. Spring:34-36.

Mays, D.A., G.L. Terman, and J.C. Duggan. 1973. Municipal compost: Effects on crop yields and soil properties. J. Environ. Qual. 2:89-92.

McConnell, D. B., A. Shiralipour, and W. H. Smith. 1993. Compost application improves soil properties. BioCycle. 34:61-63.

McDonald, L.M., M. Mandal, and R. Chandran. 2004. Compost rate effects on snap bean yield and weed population. 11-14 July, 2004. Bordentown, New Jersey. 
2004 Annual Meeting, Northeastern Branch- American Society of Agronomy. $\mathrm{pp}(4)$ (Abs).

McQuilken, M.P., J.M. Whipps., and J.M. Lynch. 1994. Effects of water extracts of a composted manure-straw mixture on the plant pathogen Botrytis cinerea. World Journal of Microbiology and Biotechnology. 10:20-26

Metzger, L. and B. Yaron. 1987. Influence of sludge organic matter on soil physical properties. Adv. Soil Sci, 7:141-163.

Millner, P. D., L. J. Sikora, D. D. Kaufman, and M. E. Simpson. 1998. Agricultural uses of biosolids and other recyclable municipal residues. p. 9-44. In R. J. Wright, W. D. Kemper, P. D. Millner, J. F. Power, and R. F. Korcak (ed.) Agricultural uses of municipal, animal, and industrial byproducts. Conserv. Res. Rep. 44. USDA Agric. Res. Serv., Washington, DC.

National Research Council. 2002. Biosolids applied to land: advancing standards and practices. The National Academic Press. Washington D.C.

Nelson, D. W. and L. E. Sommers. 1996. Total carbon, organic carbon, and organic matter. In; Methods of Soil Analysis. Part 3. Chemical Methods-SSA Book Series no. 5. Soil Science Society of America and American Society of Agronomy. pp 961-1010.

Nelson, E.B. and C.M. Craft. 1992. Suppression of dollar spot on creeping bentgrass and annual bluegrass turf with compost-amended topdressings. Plant Disease. 76:954-957.

Nelson, E.B. 1996. Enhancing turfgrass disease control with organic amendments. Turfgrass Trends. 5:1-14. 
Norrie, J. and A. Gosselin. 1996. Paper sludge amendments for turfgrass. HortScience. 31:957-960.

Nyakatawa, E. Z., K. C. Reddy and K. R. Sistani. 2001. Tillage, cover cropping, and poultry litter effects on selected soil chemical properties. Soil \& Tillage Research. 58:69-79.

Ozores-Hampton, M., and H.H. Bryan. 1993. Municipal solid waste (MSW) soil amendments: Influence on growth and yield of snap beans. Proc. Fla. State Hort. Soc. 106:208-210.

Ozores-Hampton, M., B. Schaffer, and H.H. Bryan. 1994. Nutrient concentrations, growth, and yield of tomato and squash in municipal solid waste amended soil. HortScience. 29:785-788.

Ozores-Hampton, M., T.A. Bewick, P. Stofella, D.J. Cantliffe, and T.A. Obreza. 1996. Municipal solid waste (MSW) compost maturity influence on weed seed germination. HortScience. 31:577 (Abs)

Ozores-Hampton, M. 1998. Compost as an alternative weed control method. HortScience. 33:938-940.

Ozores-Hampton, M., P.J. Stofella, T.A. Bewick, D.J. Cantliffe and T.A. Obreza. 1999. Effect of age of cocomposted MSW and biosolids on weed seed germination. Compost Sci. \& Util. 7:51-57.

Ozores-Hampton, M., T.A. Obreza, and P.J. Stoffella. 2001. Mulching with composted MSW for biological control of weeds in vegetable crops. Compost Sci. \& Util. 9:352-361. 
Ozores-Hampton, M., T. A. Obreza, P. J. Stofella, and G Fitzpatrick. 2002. Immature compost suppresses weed growth under greenhouse conditions. Compost Sci. \& Util. 10:105-113.

Paino, V., J.P. Peillex, O. Montlahuc, A. Cambon, and J.P. Bianchini. 1996. Municipal tropical compost: Effects on crops and soil properties. Compost Sci. \& Util. 4:62-69.

Parr, J.F. and G.B. Willson. 1980. Recycling organic wastes to improve soil productivity. HortScience. 15:162-166.

Paul, E.A., and F.E. Clark. 1996. Soil microbiology and biochemistry. Academic Press, San Diego, CA.

Peacock, C.H and M.M. Smart. 1995. IPM, monitoring and management plans- a mandate for the future. US Golf Assoc. Green Sec.Rec. 33:10-14.

Perucci, P. 1990. Effect of addition of municipal waste compost on microbial biomass and enzyme activities in soil. Biology and Fertility of Soil. 10:221-226.

Pinamonti, F., G. Stringari, and G. Zorzi. 1997. Use of compost in soilless cultivation. Compost Sci. \& Util. 5:38-46.

Poincelot, R.P. 1974. A scientific examination of the principles and practice of composting. Compost Sci. 24-31.

Preusch, P.L. and T.J. Tworkoski. 2002. Weed control and mineralization of nitrogen and phosphorus from composted poultry mulch in a West Virginia peach orchard. Proc. Weed Sci. Soc. Am. 18-19.

Rasnake, M. and L. Murdock. 2002. Effects of annual applications of poultry litter on tall fescue. S. W. Indiana Crop Seminar. 37-40. 
Rasnake, M., L. Murdock, and W.O. Thom. 1987. Using poultry litter on agricultural land. Univ. of Kentucky. College of Agricultural Coop. Ex. Service. AGR146.

Reeve, M. J., P. D. Smith, and A. J. Thomasson. 1973. The effect of density on water retention properties of field soils. J. Soil Sci. 24:356-367.

Robinson, J.S. and A.N. Sharpley. 1995. Release of nitrogen and phosphorus from poultry litter. J.Environ. Qual. 24:62-67.

Roe, N.E. and P.J. Stofella. 1993. Municipal solid waste compost suppresses weeds in vegetable crop alleys. HortScience. 28:1171-1172.

Ross, M. A. and C. A. Lembi. 1999. Introduction to herbicides. P 76-96. In M. Carnis (ed.) Applied Weed Science. Prentice Hall, Upper Saddle River, NJ.

Sanderson, K.C. 1980. Use of sewage-refuse compost in the production of ornamental plants. HortScience. 15:173-178.

SAS Institute. 2002. Statistical analysis software, Version 8.2. SAS Inst., Cary, NC.

Schlegel, A. J. 1992. Effect of composted manure on soil chemical properties and nitrogen use by grain sorghum. J. Prod. Agric. 5:153-157.

Schumann, G.L., H. Soares, C.M. Holden, and M.S. Switzenbaum. 1993. Relationship of traditional parameters of compost stability to turfgrass quality. Environmental Technology. 14:257-263.

Shiralipour, A., and D.B. McConnell. 1991. Effects of compost heat and phytotoxins on germination of certain Florida weed seeds. Soil and Crop Science Soc. Fla. Proc. 50:154-157. 
Shiralipour, A., D. B. McConnell, and W. H. Smith. 1992. Physical and chemical properties of soils as affected by municipal solid waste compost application. Biomass and Bioenergy. 3:261-266.

Shiralipour, A., D.B. McConnell, and W.H. Smith. 1993. Applying compost to crops. BioCycle. 34:70-72.

Sikora, L.J., C.F. Tester, J.M. Taylor, and J.F. Parr. 1980. Fescue yield response to sewage sludge compost amendments. Agron. J. 72:79-84.

Stevenson, E. 1974. Influence of peat moss on soil water retention for plants. Can. J. Soil Sci. 54:109-110.

Stevenson, E. 1982. Humus Chemistry. John Wiley \& Sons.

Sumner, M. E. and W. P. Miller. 1996. In; Methods of Soil Analysis. Part 3. Chemical Methods-SSA Book Series no. 5. Soil Science Society of America and American Society of Agronomy. pp 1201-1229.

Stofella, P.J., M. Ozores-Hampton, and D.T. Patterson. 2000. Potential of municipal solid waste compost as a biological weed control. Acta Hort. 533:211-213.

Stofella, P.J. and B.A. Kahn. 2001. Compost utilization in horticultural cropping systems. Lewis Publishers. Boca Raton London, New York.

Stratton, M.L. and J. Reichcigl. 1998. Organic mulches as soil amendments and conditioners. Handbook on soil conditioners. Marcel Dekker, Inc.

Strange, M.L., P. Elam, and R.D. Meyer. 1998. Topdressing compost on turfgrass: Its effect on turf quality and weeds. 12-14 Jan, 1998. Monterey, California. Proceedings of the California Weed Science Society. 50:28-31. 
Tester, C.F. 1989. Tall fescue growth in greenhouse, growth chamber, and field plots amended with sewage sludge compost and fertilizer. Soil Sci. 148:452-458.

Tester, C. F. 1990. Organic amendment effects on physical and chemical properties of a sandy soil. Soil. Sci. Soc. Am. J. 54:827-831.

Thomas, G. W.1996. Soil pH and soil acidity. In; Methods of Soil Analysis. Part 3. Chemical Methods-SSA Book Series no. 5. Soil Sci. Soc. Am. and Am. Soc. Agron. pp 475-490.

Tiarks, A. E., A. P. Mazurak, and L. Chesnin. 1974. Physical and chemical properties of soil associated with heavy applications of manure from cattle feedlots. Soil Sci. Soc. Amer. Proc. 38:826-830.

Tiquia, S.M. and N.F.Y. Tam. 2002. Characterization and composting of poultry litter in forced-aeration piles. Process Biochemistry. 37:869-880.

Turgeon, A.J. 1999. Turfgrass management. Prentice Hall, upper saddle river, New Jersey.

Turgeon, A. J. 1999. Turfgrass Management. Prentice Hall. Upper Saddle River, New Jersey. pp 296-298.

Tyson, S. C. and M. L. Cabrera. 1993. Nitrogen mineralization in soils amended with composted and uncomposted poultry litter. Commun. Soil Sci. Plant Anal. 24:2361-2374.

Uhvits, R. 1946. Effect of osmotic pressure on water absorbtion and germination of alfalfa seeds. Am J. Botany. 33(4):278-285. 
Vadas, P. A., J. J. Meisinger, L. J. Sikora, J. P. McMurtry, and A. E. Sefton. 2004. Effect of poultry diet on phosphorus in runoff from soils amended with poultry manure and compost. J. Environ. Qual. 33:1845-1854

Waddington, D. V., R. N. Carrow, and R. C. Shearman. 1992. Turfgrass. Am. Soc. Ag, Inc, Crop Sci. Soc. Am, Inc, Soil Sci. Soc. Am., Inc. Madison, Wisconsin

Warran, S.L., and W.C. Fonteno. 1993. Changes in physical and chemical properties of a loamy sand soil when amended with composted poultry litter. J. Environ. Hort. 11:186-190.

Watchke, T.L, and R.E. Schmidt. 1992. Ecological aspects of turfgrass communities. Turfgrass Agron. Monogr., 32:129-174.

Wei, Q. F., B. Lowery, and A. E. Peterson. 1985. Effect of sludge application on physical properties of silty clay loam soil. J. Environ. Qual. 14:178-180.

Weltzien, H.C. 1991. Biocontrol of foliar fungal diseases with compost extracts. Microbial Ecology of Leaves. eds. J.H. Andrews and S.S. Hirano. pp 430-450. New York: Springer-Verlag, Inc.

Wilson, S.B., and P.J. Stofella. 2003. Compost amended media and irrigation system influence containerized perennial salvia. J. Amer. Soc. Hort. Sci. 128:260268.

Wood, C.W., H.A. Torbert, and D.P. Delaney. 1993. Poultry litter as a fertilizer for bermudagrass: effects on yield and quality. J. Sus. Ag. 3:21-36. 